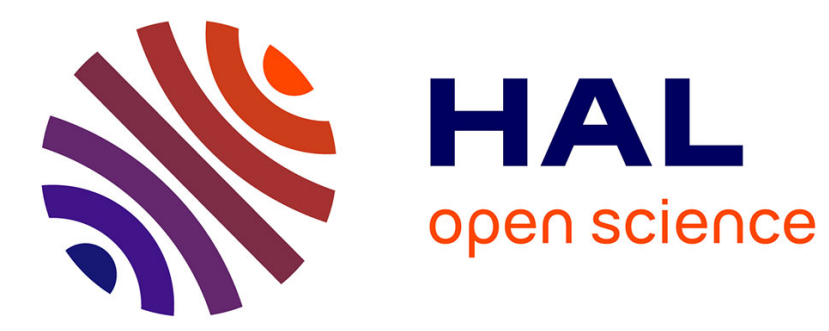

\title{
Autophagy is essential to support skeletal muscle plasticity in response to endurance exercise
}

\author{
Anthony M. J. Sanchez, Henri Bernardi, Guillaume Py, Robin B. Candau
}

\section{To cite this version:}

Anthony M. J. Sanchez, Henri Bernardi, Guillaume Py, Robin B. Candau. Autophagy is essential to support skeletal muscle plasticity in response to endurance exercise. AJP - Regulatory, Integrative and Comparative Physiology, 2014, 307 (8), pp.R956-R969. 10.1152/ajpregu.00187.2014 . hal-01837580

\section{HAL Id: hal-01837580 \\ https://hal.science/hal-01837580}

Submitted on 27 May 2020

HAL is a multi-disciplinary open access archive for the deposit and dissemination of scientific research documents, whether they are published or not. The documents may come from teaching and research institutions in France or abroad, or from public or private research centers.
L'archive ouverte pluridisciplinaire HAL, est destinée au dépôt et à la diffusion de documents scientifiques de niveau recherche, publiés ou non, émanant des établissements d'enseignement et de recherche français ou étrangers, des laboratoires publics ou privés. 


\title{
Autophagy is essential to support skeletal muscle plasticity in response to endurance exercise
}

\author{
Anthony M. J. Sanchez, ${ }^{1,2}$ Henri Bernardi, ${ }^{3}$ Guillaume Py, ${ }^{4}$ and Robin B. Candau ${ }^{4}$ \\ ${ }^{1}$ Department of Critical Care, McGill University Health Centre and Meakins-Christie Laboratories, Department of Medicine, \\ McGill University, Montreal, Quebec, Canada; ${ }^{2}$ University of Perpignan Via Domitia, Laboratoire Performance Santé \\ Altitude, EA 4604, Font-Romeu, France; ${ }^{3}$ Institut National de la Recherche Agronomique, UMR 866 Dynamique Musculaire \\ et Métabolisme, Montpellier, France; and ${ }^{4}$ Faculty of Sport Sciences, University of Montpellier 1, Montpellier, France
}

Submitted 6 May 2014; accepted in final form 11 August 2014

Sanchez AM, Bernardi H, Py G, Candau RB. Autophagy is essential to support skeletal muscle plasticity in response to endurance exercise. Am J Physiol Regul Integr Comp Physiol 307: R956-R969, 2014. First published August 20, 2014; doi:10.1152/ajpregu.00187.2014.-Physical exercise is a stress that can substantially modulate cellular signaling mechanisms to promote morphological and metabolic adaptations. Skeletal muscle protein and organelle turnover is dependent on two major cellular pathways: Forkhead box class O proteins (FOXO) transcription factors that regulate two main proteolytic systems, the ubiquitinproteasome, and the autophagy-lysosome systems, including mitochondrial autophagy, and the MTORC1 signaling associated with protein translation and autophagy inhibition. In recent years, it has been well documented that both acute and chronic endurance exercise can affect the autophagy pathway. Importantly, substantial efforts have been made to better understand discrepancies in the literature on its modulation during exercise. A single bout of endurance exercise increases autophagic flux when the duration is long enough, and this response is dependent on nutritional status, since autophagic flux markers and mRNA coding for actors involved in mitophagy are more abundant in the fasted state. In contrast, strength and resistance exercises preferentially raise ubiquitin-proteasome system activity and involve several protein synthesis factors, such as the recently characterized DAGK for mechanistic target of rapamycin activation. In this review, we discuss recent progress on the impact of acute and chronic exercise on cell component turnover systems, with particular focus on autophagy, which until now has been relatively overlooked in skeletal muscle. We especially highlight the most recent studies on the factors that can impact its modulation, including the mode of exercise and the nutritional status, and also discuss the current limitations in the literature to encourage further works on this topic.

endurance exercise; mitophagy; amino acids; protein turnover; MTOR

SKELETAL MUSCLE MASS REPRESENTS roughly $40-50 \%$ of human body weight, making it the largest tissue mass and the major amino acid reservoir (over 60\%) in the body $(8,148)$. Exercise stimulates profound modulations of cellular mechanisms that promote metabolic and morphological adaptations. Whole body protein turnover is about $300 \mathrm{~g} /$ day in a $70-\mathrm{kg}$ man (148), and exercise impacts this level, depending on exercise mode, intensity, and duration. A single acute resistance exercise can stimulate protein synthesis between 40 and $150 \%$ above rested levels (15). Endurance training is well known to increase mitochondrial function and content, which results in an oxidative phenotype and an improvement of muscle endurance with modest effect on muscle size (10). In contrast, strength and resistance training are closely related to muscle hypertrophy

Address for reprint requests and other correspondence: Anthony M. J. Sanchez, University of Perpignan Via Domitia, Laboratoire Performance Santé Altitude, Dept. Sciences et Techniques des Activités Physiques et Sportives, 7 avenue Pierre de Coubertin, 66120 Font-Romeu, France (e-mail: anthony.sanchez@univ-perp.fr).
(137). Depending on the training status and the exercise intensity and duration, a single exercise bout may cause alterations in skeletal muscle protein turnover and damage to cell components. Chronic exercise can affect the activity of protein turnover systems by modulating the expression of several protein effectors. Two major signaling pathways are mainly involved in skeletal muscle protein turnover: the Forkhead box class $\mathrm{O}$ proteins $(\mathrm{FOXO})$ that constitute a family of transcription factors, notably implicated in the regulation of protein breakdown and mitochondrial turnover (124), and the mechanistic (also known as "mammalian") target of the rapamycin complex 1 (MTORC1) pathway, associated with protein synthesis and hypertrophy (43). Importantly, the autophagy machinery, a critical pathway for cell homeostasis that had long been forgotten in skeletal muscle, has been intensively studied in the past few years. Particular emphasis has been placed on the role played by autophagic defects in disease pathogenesis, its involvement in atrophy, and the possible effects of exercise as a countermeasure $(33,136,142)$. Recently, several data have allowed a better understanding concerning several discrepan- 
cies in the literature on autophagy activation, according to the exercise modality and also, the impact of the feeding pattern on its modulation during exercise. The most critical negative regulators of autophagy are nutritional (i.e., glucose and amino acids) and hormonal (i.e., insulin) factors. MTORC1 and the adenosine monophosphate-activated protein kinase (AMPK) are presently the most recognized sensors for the availability of nutrients and energy in skeletal muscle, especially in response to exercise. Thus, as we present in this review, strong progress has been made on the molecular signaling networks that control skeletal muscle protein and organelle turnover in response to exercise, especially the crosstalk between protein translation machinery and the autophagy system. In this review, we especially discuss the recent discoveries concerning the conditions required for autophagy activation during acute exercise and the importance of this pathway in skeletal muscle plasticity in response to training. This review also attempts to provide current limitations in the literature to encourage further works on the topic.

\section{Cellular Mechanisms of Skeletal Muscle Protein Turnover and Recent Findings on the Autophagy Pathway}

FOXO factors, protein breakdown and macroautophagy. The FOXO transcription factors have multiple functions in skeletal muscle homeostasis (124). Notably, they regulate the transcription of several components of the two main mechanisms responsible for the breakdown of intracellular proteins and the elimination of dysfunctional organelles, the ubiquitinproteasome, and the autophagy-lysosome pathways (Fig. 1).

In the ubiquitin-proteasome system, E3 ubiquitin ligases (E3 ligases) select substrates for ubiquitination and targeting for breakdown by the $26 \mathrm{~S}$ proteasome. FOXO1 and FOXO3 are responsible of the transcription of muscle RING-finger protein-1 (MuRF1) and muscle atrophy F-box (MAFbx)/atrogin-1 $(66,128,133,147)$ — the most studied cytosolic E3 ligases in skeletal muscle to date-as well as the recently discovered mitochondrial E3 ligase Mul1 (82). MuRF1 promotes the breakdown of the myofibrillar proteins, by targeting myosin heavy-chain protein (MyHC) (22), myosin light-chain proteins 1 and 2 (MLC1 and MLC2, respectively) (23), and myosinbinding protein $\mathrm{C}$ (MyBP-C) (23). Notably, during fasting, another RING-finger E3 ligase, tripartite motif-containing protein 32 (Trim32), targets the thin filament components (i.e., troponins, tropomyosin, and actin) and Z-band $\alpha$-actinin, thus promoting their degradation (24). MAFbx/atrogin-1 represses the transcription and translation of muscle genes throughout the degradation of the myogenic transcription factors MyoD (139) and myogenin (63), and the eukaryotic initiation factor of translation eIF3f $(25,26,127)$. In addition, other E3 ligases are involved in muscle catabolism, such as the recently identified zinc-finger protein 216 (ZNF216), which is found in skeletal muscle and may also function as an effector of FOXO proteins in muscle atrophy (51). However, little is known about their specific functions or targets, especially in response to exercise stimulus.

Macroautophagy, also called the autophagy-lysosome pathway, is an important degradation system ensuring cell metabolism and cell component turnover. Deletion of the autophagyspecific gene (Atg) number 7 (Atg7) causes marked accumulation of abnormal mitochondria, sarcomere disorganization, and deleterious alteration in membranous structures, all of which results in atrophy and an age-related loss in force (91). Importantly, a huge number of recent studies evidenced that autophagic defects were found to play a critical role in several diseases of pathogenesis, including Pompe and Danon diseases (142). These findings strongly suggest the essential role of autophagy in maintaining muscle integrity. However, excessive autophagy can lead to substantial muscle disorders (129). For example, a role of autophagy in atrophy has been recently evidenced during LPS-mediated endotoxemia $(60,101)$.

The autophagic process begins with the capture of substrates into a vesicle called the autophagosome; this vesicle then fuses with a lysosome to form an autophagolysosome (often referred to as the autolysosome) and the sequestered material is degraded by lysosomal hydrolases. The autophagy machinery needs the Atg proteins - several of which are transcriptionally regulated by FOXO3 $(87,161)$-for autophagosome biogenesis and maturation and several enzymatic systems. The Unc51-like kinase (ULK1, also called Atg1 in yeast)/Atg13/ FIP200/Atg101 and Beclin-1/vacuole protein sorting 34 (Vps34, also called PI3K class III) complexes integrate several stress signals and are necessary for autophagy initiation (65, $67,93,135)$. These proteins operate with other Atgs to promote the initial assembly of the autophagosomal membrane. Importantly, the molecular events by which ULK1 regulates autophagy in mammals remained relatively speculative until the recent discovery by Russell et al. (116), who identified Beclin-1 as a substrate of ULK1 following amino acid withdrawal. Beclin-1 phosphorylation by ULK1 at Ser-14 is necessary for Vps34 activation and full autophagic induction (116). Two other complexes are crucial for the formation of autophagosome membrane, the Atg12/Atg5/Atg16 complex $(98,99,113)$ and the conjugation system of the microtubuleassociated protein 1 light chain 3 (LC3, initially named Atg8 in yeast) (64), as well as its homologs GABAA receptor-associated protein (GABARAP) and Golgi-associated ATPase enhancer (GATE-16). Pro-LC3 is first cleaved by the cysteine protease Atg4 to its mature form, LC3I. The latter is subsequently conjugated to the lipid phosphatidylethanolamine (PE) of the forming autophagosomal membrane by Atg7 and Atg3, the PE-LC3-I conjugate referred to as LC3-II. This event is crucial for membrane fusion and substrate selection for degradation (105). The autophagy adapter p62/SQSTM1 (sequestosome 1), which contains multiple protein-protein interaction domains, interacts with LC3 (11), allowing the entry of ubiquitinated cargo into the autophagosome (108). In a final step, the autophagosome fuses with the lysosome, and the lysosomeassociated membrane protein 2a (LAMP2a), a glycoprotein, takes on a critical role in this event (56).

Autophagy was long considered to be a nonselective degradation system, but it is now widely acknowledged that autophagy promotes the degradation of specific cell components. The selective autophagic elimination of defective mitochondria is called mitophagy. Mitochondrial life cycle includes the biogenesis, the maintenance, and also the clearance of damaged or inefficient mitochondria. Fission and selective fusion events govern mitochondrial segregation, as well as elimination by autophagy, and an increase in mitochondrial fission has been showed to be permissive for induction of mitophagy (141). An accumulation of reactive oxygen species (ROS) and the dissipation of the mitochondrial membrane potential may lead to raised ubiquitination of mitochondrial proteins, driving 


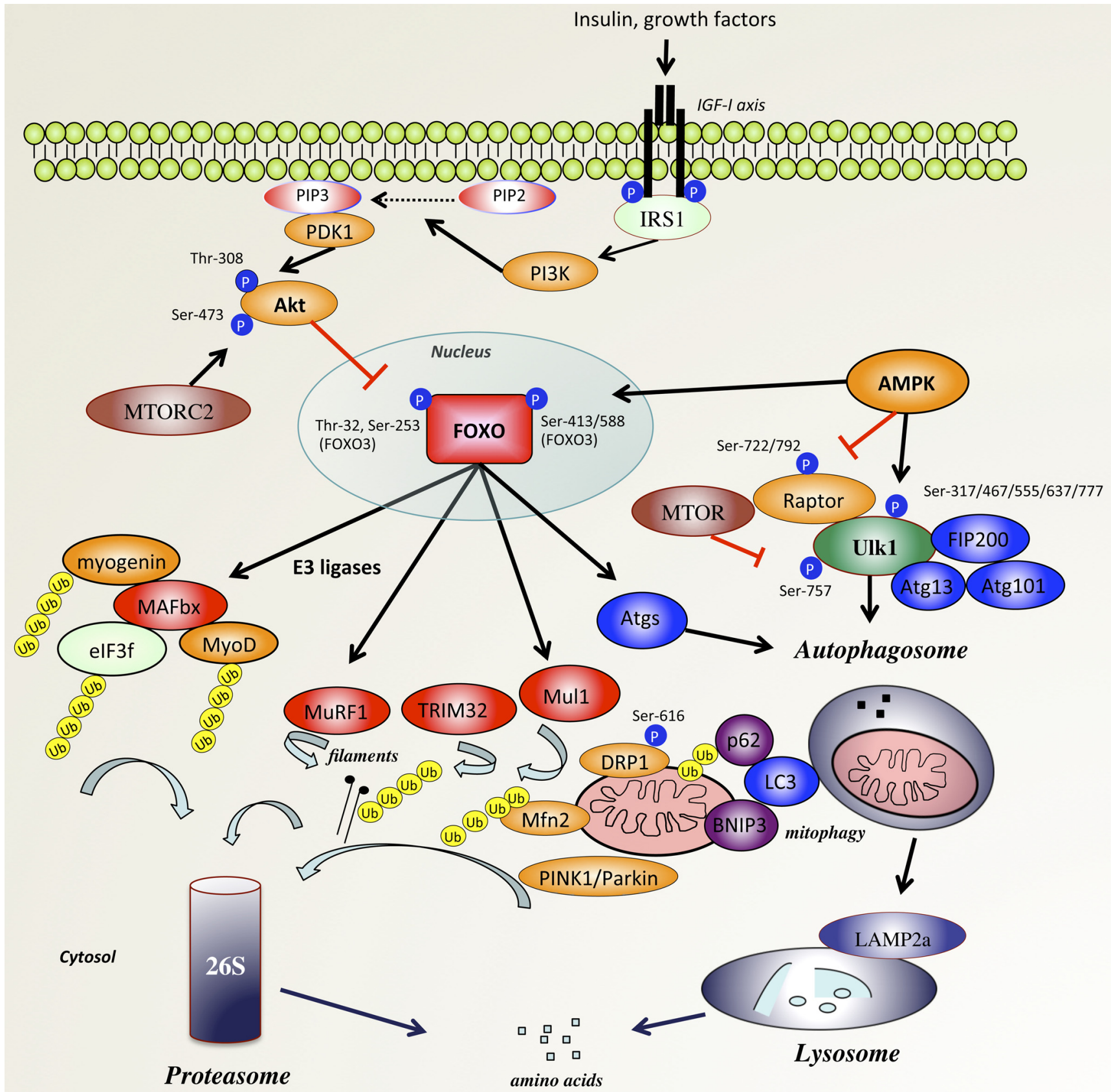

\section{Protein Breakdown}

Fig. 1. Forkhead box class O proteins (FOXO)-dependent protein breakdown and mitophagy in skeletal muscle. FOXO transcription factors are phosphorylated and inhibited by Akt in response to insulin/growth factor stimulation. Under conditions of energy stress, AMPK phosphorylates and activates FOXO3. FOXO factors increase the transcription of MAFbx/atrogin-1 and MuRF1, which are E3 ligases involved notably in the degradation of the eukaryotic initiation factor 3f (eIF3f), MyoD, and myogenin for the first one, and several sarcomeric proteins for the second one. TRIM32 is another RING-finger E3 ligase that targets the thin filament components. FOXO proteins also increase the transcription of the mitochondrial E3 ligase Mul1, leading to the ubiquitination and degradation of Mfn2 and mitophagy during skeletal muscle atrophy. Mul1 has also been reported to stabilize the mitochondrial fission protein DRP1, in vitro, resulting in mitochondrial fragmentation. Mitochondrial depolarization stabilizes PINK1, permitting the recruitment of the E3 ligase Parkin to damaged mitochondria for mitophagy. FOXO proteins control the transcription of several Atgs that have critical roles in autophagosome biogenesis, including LC3. The autophagy adapter p62/SQSTM1 binds directly to LC3 to facilitate sequestration of ubiquitinated protein aggregates by autophagosomes. BNIP3 is also involved in mitophagy by binding to LC3 and recruiting the autophagosome to damaged mitochondria. Among Atgs, ULK1 is involved in autophagy initiation and can be phosphorylated by the mechanistic target of rapamycin (MTOR), leading to its inhibition, and by AMPK, leading to its activation. LAMP2a is a glycoprotein that plays a critical role in autolysosome formation. 
mitochondrial fission and mitophagy $(111,159)$. The mitophagy process involves mechanisms requiring two Parkinson's disease factors, the mitochondrial kinase PINK1 (PTENinduced putative kinase protein 1, PTEN being a phosphatase, and tensin homolog) and the RING-between-RING E3 ligase Parkin $(92,146)$. Although little is known about the molecular basis for these interactions, especially in skeletal muscle, a recent study showed that PINK1 is activated by mitochondrial membrane potential depolarization, and it stimulates Parkin activity through phosphorylation of its ubiquitin-like domain (Ubl) (75). Another ubiquitin ligase involved in mitophagy is the mitochondrial E3 ligase Mul1 presented above, which has been associated with skeletal muscle atrophy in response to muscle-wasting stimuli (82). Upregulation of Mul1 results in ubiquitination and degradation of the mitochondrial fusion protein Mfn2 and exacerbated mitochondrial fission, leading to mitochondrial elimination in skeletal muscle (82). Mul1 has also been reported to stabilize the dynamin-related protein 1 (DRP1) in vitro, resulting in mitochondrial fragmentation (14). Lastly, the BCL2 (B-cell lymphoma 2)/adenovirus E1B 19$\mathrm{kDa}$ interacting protein-3 proteins (BNIP3 and BNIP3L) are also involved in mitophagy process by binding to LC3 and recruiting the autophagosome to damaged mitochondria (106).

Among the accurate methods to measure autophagic activity, the so-called "autophagic flux assay" based on LC3 protein turnover is one key measure that should be performed when possible (74). Inhibitors of autophagic activity, such as bafilomycin $\mathrm{A} 1, \mathrm{NH} 4 \mathrm{Cl}$, and chloroquine, which prevent the fusion between autophagosomes and lysosomes or inhibit lysosomal proteases, are commonly used to assess autophagic flux. This removes the problem of incorrect interpretation of LC3 data: an increase in LC3B-II levels alone could also mean a block in the latter stages of autophagy, while a reduction in LC3B-II could also mean enhanced autophagy with increased in lysosomal degradation. In addition to LC3, the degradation of p62 or another receptor, such as NBR1, may be used to study autophagic degradation (74), since they are incorporated into the completed autophagosome and are degraded by the lysosomes. Thus, p62 accumulates when autophagy is inhibited, and decreases when autophagy is induced. However, an increase in p62 mRNA levels can occur in certain conditions, for example when exercise is performed during fasting (61). Increased p62 mRNA content can potentially lead to an increase in the translation of new p62 proteins, and in this case, a significant decrease in p62 protein level is not necessarily observed, while an increase in autophagic flux can still take place. Thus, interpretation of autophagy only based on p62 protein level is not a strong approach.

Collectively, these recent studies highlight that FOXO transcription factors are central regulators of protein breakdown and autophagy pathway. Importantly, the recent data on the signaling pathways that regulate skeletal muscle macroautophagy have provided much greater insight into this process in muscle tissue. Although the understanding of cellular mechanisms regulating mitophagy is emerging, further studies in autophagy and organelle turnover have to be encouraged.

Mechanistic target of rapamycin pathway, protein translation and ULK1 complex. The IGF-1/Akt/MTORC1 axis is the main signaling pathway for protein synthesis in skeletal muscle (Fig. 2). Upon growth factor stimulation, the insulin-like growth factor 1 (IGF-1) receptor is phosphorylated and recruits the insulin receptor substrate 1 (IRS1), leading to the activation of the lipid kinase PI3K (phosphoinositide 3-kinase). PI3K promotes the transfer of a phosphate group to the membranebound phosphatidyl inositol diphosphate (PIP2), thus generating phosphatidyl inositol triphosphate (PIP3), which recruits two additional kinases: Akt [also called protein kinase B (PKB)] and the phosphoinositide-dependent kinase-1 (PDK1) $(1,134)$. Akt is then activated by phosphorylation at Thr-308 by PDK1 (1), and it inactivates tuberous sclerosis complex $1 / 2$ (TSC1/2) by phosphorylation at Thr-1462, promoting the mechanistic target of rapamycin (MTOR) activation by RhebGTP $(21,37,57)$. MTORC1, which is composed of MTOR, the regulatory associated protein of MTOR (RPTOR), a prolinerich Akt substrate of $40 \mathrm{kDa}$ (PRAS40), a DEP domaincontaining MTOR-interacting protein (DEPTOR), and MTORassociated protein LST8 homolog (mLST8/GßL) $(68,69,80$, 143 ), binds to the eukaryotic initiation factor $3 \mathrm{f}$ (eIF3f), a scaffold protein that allows MTOR to phosphorylate the ribosomal protein p70S6 kinase 1 (S6K1) at Thr-389 (52). S6K1 phosphorylates several substrates involved in the regulation of protein translation, including the ribosomal protein S6 at Ser235, Ser-236, Ser-240, Ser-244, the eukaryotic translation initiation factor 4B (eIF4B) at Ser-422, and the eukaryotic elongation factor 2 (eEF2) kinase at Ser-366 $(52,118)$. S6K1 is also phosphorylated by PDK1 at Thr-229, which is required for its full activation (110). In addition to S6K1, MTOR also regulates the eukaryotic translation initiation factor 4E-binding protein 1 (4E-BP1) by phosphorylation at Thr-37 and Thr-46, inducing its dissociation from eIF4E to promote the assembly of the preinitiation complex and the recruitment of the translation initiation factor eIF4G to the $5^{\prime}$ end of mRNAs $(47,48$, 160). It is of note that MTORC2, which is composed of MTOR, the rapamycin-insensitive companion of MTOR (RICTOR), mLST8/G $\beta$ L, DEPTOR, and the mammalian stressactivated protein kinase interacting protein 1 (mSIN1) $(34,80$, 130), phosphorylates Akt at Ser-473 (131), facilitating PDK1mediated Akt phosphorylation at Thr-308, thereby resulting in a further activation of the MTORC1 pathway (131).

The MTORC1 complex is sensitive to nutrient availability and growth factors, and it regulates several cellular processes, including cell growth, proliferation, motility, survival, protein synthesis, and ribosomal biogenesis. In addition to its fundamental role in protein translation, MTOR is now presented as the dominant regulator of autophagy in skeletal muscle, since MTOR/RPTOR negatively regulates autophagy initiation through physical association with ULK1 complex (20). More precisely, MTOR phosphorylates ULK1 at Ser-757, preventing ULK1 activation and autophagy initiation (71). Importantly, MTOR dissociation from ULK1 seems also necessary to induce Beclin-1 phosphorylation by ULK1 and Vps34 activation following amino acid withdrawal (116).

Thus, MTOR, which is known to be a major factor in protein translation, is now assumed to be a key regulator of both protein synthesis and the autophagy pathway through ULK1 complex regulation in skeletal muscle. Further work is required to determine whether MTOR is involved in the regulation of other components than the ULK1 complex in the autophagic machinery.

AMPK regulates both protein synthesis and breakdown pathways. AMPK is a master actor in skeletal muscle homeostasis (125) that is activated by various energy stress conditions, including nutrient deprivation (122) and vigorous exer- 

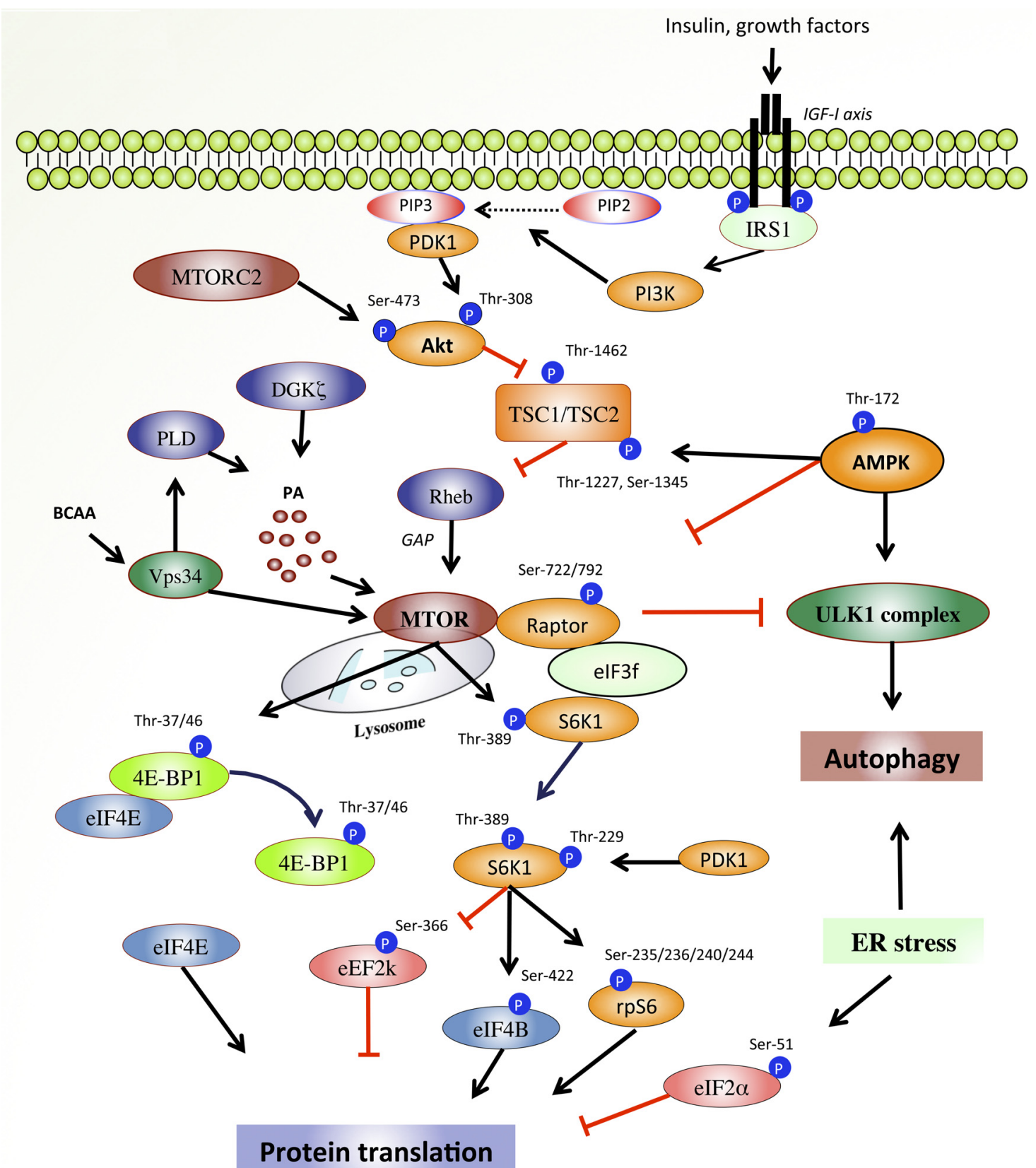

Fig. 2. Signaling pathways involved in MTOR regulation and protein synthesis. Upon IGF-1 axis activation, the IGF-1 receptor is phosphorylated and recruits IRS1, leading to the activation of the lipid kinase PI3K. PI3K phosphorylates the membrane-bound phospholipid PIP2 to generate PIP3, which recruits Akt and PDK1. Akt is activated by phosphorylation at Thr-308 by PDK1. Akt then phosphorylates and inactivates TSC1/TSC2 complex, a Rheb inhibitor. MTOR is, thus, activated by Rheb, binds to the scaffold protein eIF3f and modulates protein synthesis by phosphorylating S6K1 and 4E-BP1. S6K1-mediated regulation of translation occurs, in part, through phosphorylation of rpS6, eIF4B and eEF2k. Phosphorylation of 4E-BP1 by MTOR promotes its dissociation from eIF4E and allows the assembly of the preinitiation complex. MTOR in association with rictor (MTORC2) phosphorylates and fully activates Akt on Ser-473. In response to mechanical stimuli, MTOR is also activated by branched-chain amino acids, Vps34, and by phosphatidic acid (PA). PA can be synthesized by both PLD and DAGל. Amino acids are involved in the recruitment of MTOR to the lysosomal surface, where MTOR can be activated by Rheb. MTOR inhibits autophagy through ULK1 complex, whereas AMPK positively regulates this complex. ER stress can lead to protein translation inhibition through phosphorylation of eIF2 $\alpha$.

cise (153). AMPK is phosphorylated by several enzymes (i.e., LKB1, CaMKK $\beta$, TAK-1) when the ratio AMP/ATP is increased under conditions of energy deficit (125). In response to exercise, AMPK activation depends on the training status, since training attenuates exercise-induced increases in skeletal muscle free AMP:ATP ratio (94). When activated, AMPK promotes metabolic changes to preserve bioenergetic state by increasing glycolysis flux (88) and fatty acid oxidation (96,
$144,150,151)$, and by inhibiting glycogenogenesis $(3,18)$ and fatty acid and cholesterol synthesis $(17,19,38)$. In addition, AMPK has been recently showed as a critical regulator of skeletal muscle protein turnover (125). AMPK reduces both the initiation and the elongation of ribosomal peptide synthesis through the inhibition of the MTORC1 pathway in both in vitro and in vivo models $(13,109)$. AMPK inhibits the MTORC1 pathway through two ways, the phosphorylation of RPTOR at 
Ser-722 and Ser-792 (46) and the phosphorylation of TSC2 at Thr-1227 and Ser-1345 (57). MTORC1 inhibition by AMPK contributes to ULK1 activation under conditions of energy stress (77). AMPK also interacts with and phosphorylates ULK1 at several residues (Ser-317, Ser-555, Ser-467, Ser-637, Ser-777) to induce its activation and autophagy initiation, notably in muscle cells $(30,31,71,77,81,126)$. Interestingly, ULK1 can phosphorylate, in turn, the three AMPK subunits during starvation in HEK-293 cells, constituting a negative feedback loop (81). However, the latter event remains to be clarified in skeletal muscle, particularly according to the context of autophagy activation. Importantly, in cellulo studies revealed that withdrawal of amino acids activates autophagy, in part, through an increase in cellular $\mathrm{Ca}^{2+}$ that leads to the activation of the CaMKK $\beta$-AMPK pathway (39). In this model, MTOR is inhibited in a $\mathrm{Ca}^{2+}$-sensitive manner, and ULK1 is phosphorylated at Ser-555 by AMPK, both events taking part in autophagy initiation. AMPK also promotes the transcription of several Atgs by the activation of FOXO3 in skeletal muscle (126). By increasing FOXO3 activity, AMPK is also involved in the degradation of myofibrillar components through the induction of the E3 ligases MAFbx/atrogin-1 and MuRF1 (104).

In summary, AMPK has been recently identified as a new important player in skeletal muscle autophagy. Despite these recent discoveries, AMPK involvement in specific forms of autophagy, for example, mitophagy, is currently poorly studied and solely suggested in skeletal muscle.

\section{Exercise and MTOR Signaling}

Both protein synthesis and degradation rates are decreased during muscle contractions, and the effect differs among muscle fiber types (16). For example, protein synthesis can be decreased by $88 \%$ in gastrocnemius (white) fibers, $53 \%$ in tibialis anterior, whereas it is not changed in soleus muscle in response to the same exercise $(15,16)$. The Akt/MTOR pathway is a critical regulator of cell size in skeletal muscle under conditions of increased external loading. Although a single bout of high-frequency electrical stimulation or sprint exercise induces a transient increase in Akt (Thr-308/Ser-473) and MTOR (Ser-2448) phosphorylation during the recovery period $(32,102)$, no change is usually observed after endurance exercise for Akt, whatever the intensity or species (mice/rats) $(4,102)$. These findings indicate that Akt may be more involved in response to strength, resistance, or sprint exercise than endurance exercise. Nonetheless, the MTOR axis is altered in response to endurance exercise. Although protein synthesis markers are globally decreased during high-intensity exercise, increases in MTOR, 4E-BP1 phosphorylation, S6K1, eEF2, and S6 phosphorylation are generally reported in mice and human subjects during the recovery from moderate or exhaustive endurance exercise $(89,90,107)$. This suggests that endurance exercise modulates protein synthesis, and signals other than Akt may converge on MTOR after this type of exercise. Protein synthesis also decreases during resistance exercise, in part, due to AMPK activation, but it increases from $\sim 1 \mathrm{~h}$ postexercise, and AMPK activity becomes less pronounced from $2 \mathrm{~h}$ (28). A recent study investigated the influence of AMPK vs. MTORC1 signaling on converting differentiated exercise into training-specific adaptations in trained subjects and found that MTORC1 pathway appeared to be preferentially enhanced after strength or resistance exercise, whereas AMPK pathway was less specific for differentiated exercise (145).

The implication of the protein synthesis pathway has been more intensively studied in loading models than during endurance exercise. Several factors have been suggested to regulate MTOR activity, and the translational machinery in response to mechanical stimuli, such as the PI3K/Akt axis activated via the release of growth factors $(55,149)$, exogenous nutrients (53), intracellular $\mathrm{Ca}^{2+}(54)$, and the extracellular signal-regulated kinases (ERK) $(29,97)$. However, none of them appear to be essential for exercise-induced muscle growth $(53-55,158)$. Moreover, a study of mice with muscles expressing a dominant-negative IGF-I receptor demonstrated that an increased mechanical load induced muscle hypertrophy by activating Akt and S6K1 independently of the IGF-1 receptor (132). One explanation may be that mechanical stimuli activate phospholipase D (PLD) and the lipid second messenger phosphatidic acid (PA), resulting in enhanced binding of PA to the FKBP12rapamycin binding (FRB) domain on MTOR and the subsequent activation of MTOR $(54,158)$. However, changes in PLD activity are not required for PA accumulation and MTORC1 activation (157), and diacylglycerol (DAG) and the activity of the DAG kinases (DGKs) have recently been implicated in PA accumulation in response to mechanical stimulation (157). The zeta isoform of DGK (DGK $\zeta)$, which is responsible of the biosynthesis of PA through DAG phosphorylation, is currently assumed to play the major role in mechanically induced increases in PA concentration and MTOR signaling (157). Furthermore, a plethora of studies has been conducted to identify anabolically active nutrients for skeletal muscle. For example, experiments in which amino acids are infused highlight the crucial role of essential amino acids (EAAs) as the principal mediators for stimulation of muscle protein synthesis $(2,6,7,103,140)$. In response to exercise, the increase in the rate of protein synthesis can be improved by branched-chain amino acids (BCAAs), particularly leucine absorption (12). It is noteworthy that protein intake immediately after exercise permits more anabolic effects than when ingested at some later time (9). Mechanistically, BCAAs induce the phosphorylation of MTOR and S6K1 in human muscle during recovery, suggesting that amino acids regulate MTOR activity (12). Recent work has demonstrated that amino acids promote MTORC1 activation at the lysosome via a cascade involving RAG GTPases, the Ragulator complex, and vacuolar $\mathrm{H}^{+}$-ATPase (v-ATPase) (123). According to this model, amino acids localize MTORC1 through RAG proteins to the lysosome, where its activator Rheb, which is present at the lysosome surface, interacts with and activates MTOR (123).

Furthermore, a recently discovered truncated splice variant of PGC- $1 \alpha$, the PGC- $1 \alpha 4$ isoform, has also been proposed as a candidate for investigating muscle adaptation to exercise and protein synthesis modulation. While PGC- $1 \alpha 1$ promotes mitochondrial biogenesis and the expression of several genes encoding the OXPHOS (oxidative phosphorylation) machinery in response to endurance exercise $(5,44,154)$, myotubes or muscles expressing PGC- $1 \alpha 4$ isoform show robust hypertrophy in mice and humans (115). In vivo PGC- $1 \alpha 4$ expression results in increased S6K1 and S6 phosphorylation levels, suggesting a rise in MTOR pathway activity (115). PGC-1 $\alpha 4$ 
also induces several members of the IGF-binding protein family and represses the transcript level of myostatin (115), a strong negative regulator of skeletal muscle growth (95). However, the expression of PGC- $1 \alpha$ variants has been assessed in response to both acute and chronic exercise in parallel to measurements of muscle size and strength, and the authors reported no link between PGC- $1 \alpha 4$ and these parameters in humans (83). In agreement, resistance exercise does not specifically induce the truncated forms of PGC- $1 \alpha$ (i.e., PGC- $1 \alpha 4$ and NT-PGC-1 $\alpha$ ), since they increase with both endurance and resistance exercise (155). Thus, even if PGC- $1 \alpha 4$ appears not specifically related to skeletal muscle adaptation to resistance exercise, its expression during cancer cachexia shows strong resistance to atrophy (115), thereby PGC- $1 \alpha 4$ modulation offers important perspectives in the fight against muscle disease.

In summary, although the MTOR pathway is inhibited during endurance exercise, especially for high-exercise intensity and duration, the modulation of protein synthesis markers is more pronounced during the recovery period of strength and resistance exercises. Mechanistically, the regulators of MTOR activity in response to overload training are numerous, but the recent data on DGK $\zeta$ suggest promising new perspectives for investigating the signaling pathways that regulate muscle growth in response to training.

\section{Exercise and Skeletal Muscle Autophagy}

Exercise and autophagic-deficient mice. The first study that observed autophagic vacuoles during exercise dates back to 1984 (121). By using electron microscopy, the authors observed autophagosome formation after exhaustive exercise more prominently in oxidative fibers rich in mitochondria than in glycolytic fibers. Nevertheless, until recently, the role of the autophagy-lysosome system in skeletal muscle has been widely neglected. Yet recent data in mice bearing muscle-specific suppression of the autophagy system have highlighted 1) its importance in regulating skeletal muscle mass, 2) its importance in adaptation to exercise stimuli, and 3) its protective function, as the animals developed severe muscle weakness, atrophy, and decreased muscle contractility. The first illustration is the study by Grumati et al. (45), which demonstrated that training exacerbates the dystrophic phenotype of collagen VI-null mice, which present impaired autophagy. These mice showed an accumulation of defective mitochondria, as well as significant degeneration and exacerbated apoptosis in muscle, supporting the importance of autophagy in muscle adaptation to endurance training. At the same time, He et al. (50) generated mice with mutations in BCL2 phosphorylation sites, thus preventing stimuli-induced disruption of the BCL2-Beclin-1 complex and autophagy activation. These mice presented decreased endurance performance and altered glucose metabolism, including a decrease in the sarcolemma relocalization of GLUT4 (glucose transporter type 4) during acute exercise, which strongly indicated that autophagy is essential for regulating the metabolic effects associated with exercise in skeletal muscle (50). The authors also demonstrated that autophagiadeficient mice lose the benefits of chronic exercise-mediated protection against high-fat diet-induced glucose intolerance. Indeed, training in these mice failed to decrease the high-fat diet-induced elevation in cholesterol, serum triglycerides, and leptin, an adipokine that plays a role in regulating energy intake and expenditure, including hunger (50).

In summary, the autophagy pathway appears to be essential for muscle cell homeostasis. Moreover, autophagy mediates several metabolic effects related to exercise and appears to be a critical factor for endurance performance since its ablation leads to impaired metabolic properties and drastic decreases in performance.

Autophagic response to acute endurance exercise and the importance of dietary factors. The autophagy machinery in response to exercise was first explored in humans during ultra-endurance exercise, which is known to be associated with damaged proteins and organelles, exacerbated oxidative stress and the accumulation of misfolded proteins (70,117). Several autophagic markers, including LC3B, Atg4b, Atg12, BNIP3, and cathepsin L mRNA, were upregulated immediately after a 24-h ultra-endurance exercise (58), as were the protein levels of some of these markers (i.e., LC3B-II and Atg12) (59). Also, the MuRF1 protein level, but not MAFbx, increased in coordination with a rise in AMPK phosphorylation and a decrease in FOXO3 phosphorylation (Thr-32); notably, proteasome $\beta 2$ subunit and cathepsin $\mathrm{L}$ activities increased in response to the exercise. These data support the involvement of the AMPKFOXO3 axis in muscle catabolism and reveal that the activity of both the proteasome and lysosome are increased in response to such prolonged exercise (59). It can be speculated that the rise in these catabolic activities makes amino acids available as an alternative energy substrate during this type of effort, since a small amount of energy can be derived from oxidation of amino acids during endurance exercise $(40,112)$. Moreover, autophagia-induced amino acid availability would permit the protein translation of several genes induced during exercise. Indeed, even though global protein synthesis is greatly decreased during exercise, muscle cells cannot afford to completely stop protein synthesis. The removal or recycling of damaged cell constituents is also vital for the maintenance of skeletal muscle homeostasis during exercise. In addition, mechanical stimuli induce changes in gene expression that affect metabolism and promote adaptations in muscle function and muscle mass (138). This increased catabolic state might also induce cell adaptation to the exercise, such as the initiation of the first step in mitochondrial remodeling.

Regarding the more common exercise durations, we examined the modulation of protein turnover markers at several time points of a progressive endurance exercise and observed that the autophagy initiator ULK1 was quickly phosphorylated on AMPK phosphorylation residues (Ser-317 and Ser-555) in oxidative muscles. This alteration was followed by a decrease in MTOR-mediated phosphorylation of ULK1, suggesting autophagy initiation during low-intensity exercise (107). However, sedentary mice were used in this study, which might explain the rapid activation of AMPK and the subsequent alterations in ULK1 phosphorylation during the exercise. Supporting this hypothesis, several important regulators of autophagy, including AMPK in muscle cells (126), present activities that can be finely modulated by training status (94). With regard to autophagic flux index, an increase in LC3B-II and a decrease in p62 expression were found from $120 \mathrm{~min}$ of exercise to time to exhaustion (107), consistent with an increase in autophagic activity in response to a common endurance exercise. Importantly, Saleem et al. (120) found no 
increase in several autophagic markers (i.e., LC3B-II, p62, Beclin-1, and Atg7) with an exercise duration of about $90 \mathrm{~min}$, even though the intensity (physiologically equivalent to running at $\sim 75 \%$ of $\dot{\mathrm{V}}_{\mathrm{O}_{2} \max }$ ) was more elevated than for the latter study. Consistent with this, Kim et al. (73) also failed to observe an alteration in LC3B-II protein level in mice immediately after $50 \mathrm{~min}$ of moderate treadmill exercise (at a speed of $12.3 \mathrm{~m} / \mathrm{min}^{-1}$ with a slope of $5^{\circ}$ ). In the same study, the authors found that several autophagic markers (i.e., Beclin-1, LC3B-II, Atg7, and LAMP2a) declined during the recovery period $(3,6$, and $12 \mathrm{~h}$ postexercise), indicating that the autophagy-lysosome machinery quickly decreases during the recovery period of a moderate-intensity exercise. Taken together, the aforementioned studies strongly suggest that exercise duration is an important factor for elevating skeletal muscle autophagy. It can be speculated that during endurance exercise, AMPK activation and/or MTORC1 signaling pathway inhibition modulates FOXO3a activity and the ULK1 axis to mobilize protein degradation as an internal energy source for alternative nutrient production and energy substrates when exercise intensity/duration becomes high. In addition, the autophagy system is required for the maintenance of cellular functions and the appropriate response to multiple types of stress. Thus, during prolonged exercise, the autophagy-lysosome pathway may function as a compensatory mechanism to prevent cellular function loss caused by constraints linked to metabolic stress.

An important point to bear in mind is that the mechanisms that regulate protein turnover and autophagy are responsive to feeding. Increasing amino acids immediately after exercise through an exogenous source results in attenuation of exerciseinduced protein breakdown and a concomitant increase in protein synthesis (15). However, no specific study is currently available concerning the effect of such a strategy on lysosomal proteolysis. Nevertheless, from a mechanistic viewpoint, Jamart et al. (61) recently found that exercise performed in the fasted state shows a higher increase in LC3B-II level compared with the fed state, suggesting a greater autophagic flux when exercise is performed during fasting. The authors also observed modulation of several autophagy markers, including an increase in GABARAPL1 lipidation and cATG12 protein level, as well as a rise in the levels of mRNA encoding for p62, LC3B, and GABARAPL1. These results are arguments in favor of a higher involvement of the autophagic machinery when exercise is performed in the fasted state (61). Importantly, exercise conducted in the fasted state promotes the expression of the mitophagic markers BNIP3 and Parkin, even for $90 \mathrm{~min}$ of low-intensity exercise, in contrast to what is observed in the fed state (61), suggesting that mitophagy machinery is activated more quickly in the fasted state. Moreover, in this condition, the inhibition of MTOR seems to play a more prominent role than AMPK in autophagy induction (61). Since MTOR and autophagy are responsive to amino acid availability, furthers studies are needed to also evaluate the impact of essential amino acids supplementation on the timing and extent of autophagy activation during exercise.

In summary, it is becoming apparent that the autophagy machinery is induced by endurance exercise (Fig. 3), probably in an exercise duration-dependent manner. However, the lack of training background in the animals used in these studies could explain the quick induction of autophagy that was observed. The impact of training in acute autophagic response needs to be further addressed. In addition, exercise studies need to always be put in the context of diet since feeding pattern impacts the timing and extent of activation of autophagy.

Autophagic response to acute resistance exercise. The involvement of the autophagy-lysosome pathway during strength and resistance exercise has been less well defined to date. However, the study conducted in humans by Fry et al. (36) showed that two autophagic markers, the conversion of LC3B-I to LC3B-II and the GABARAP mRNA level, are depressed in young and older adult skeletal muscle following an acute bout of resistance exercise (36), suggesting a decrease in autophagy. Interestingly, the study by Glyn and coworkers did not show modulation of LC3B-II protein content $1 \mathrm{~h}$ after resistance exercise, but LC3B-II levels can be downregulated following essential amino acids plus carbohydrate $(\mathrm{CHO})$ ingestion, suggesting that autophagy pathway may play a role in the regulation of protein breakdown in response to nutrients (41). Muscle protein breakdown following resistance exercise seems to be more the consequence of an increase in the activity of the ubiquitin-proteasome pathway than the autophagy-lysosome system, since the E3 ligases MAFbx and MuRF1 are strongly upregulated in contrast to the above-mentioned autophagic markers (36). The only autophagic marker shown to be increased in response to resistance exercise $(3 \mathrm{~h}$ postexercise and longer) to date is the class III PI3K Vps34 $(85,86)$, but its role in autophagy after such an exercise has not been confirmed. Vps34, being stimulated by essential amino acids, such as leucine (86), also regulates MTOR activity through PLD (156), and this induction in response to resistance exercise should be more related to protein synthesis than autophagy.

To summarize, few works have shown a depression of autophagy in response to acute resistance exercise, and autophagy can be modulated by nutritional intervention (i.e., amino acid and carbohydrate supplementation) during the recovery period of such an exercise. To date, autophagy activation appears nonessential for muscle adaptations to resistance exercise compared with endurance exercise (Fig. 3).

Exercise, autophagy, and organelle turnover. Although autophagy was initially considered as a nonselective bulk degradation process, it is now known to target protein aggregates and organelles, such as mitochondria. Endurance exercise requiring high-energy production levels is likely to induce ROS production and metabolic disturbances that potentially damage the mitochondria, especially when the intensity becomes severe $(27,42,78,119)$. The mitophagy pathway might be involved in the removal and recycling of dysfunctional mitochondria during exercise and, thus, limit cellular alterations and optimize cell functions. In support of this hypothesis, it has been suggested that exercise tips the mitochondrial fusion/ fission balance in favor of fission, thereby probably leading to mitophagy $(59,61,107)$. These studies highlight that exercise quickly raises the phosphorylation of the mitochondrial fission protein DRP1 (Ser-616), a key actor of mitochondrial and peroxisomal division, without any change in mitochondrial fusion markers. Characterizing the mitophagic process in vivo is a challenge. To date, mitophagy has been studied only with several mRNA or protein markers like BNIP3, Parkin/PINK1, and Mul1, none of which is sufficient to clearly determine whether or not this process operates during exercise. Thus, 


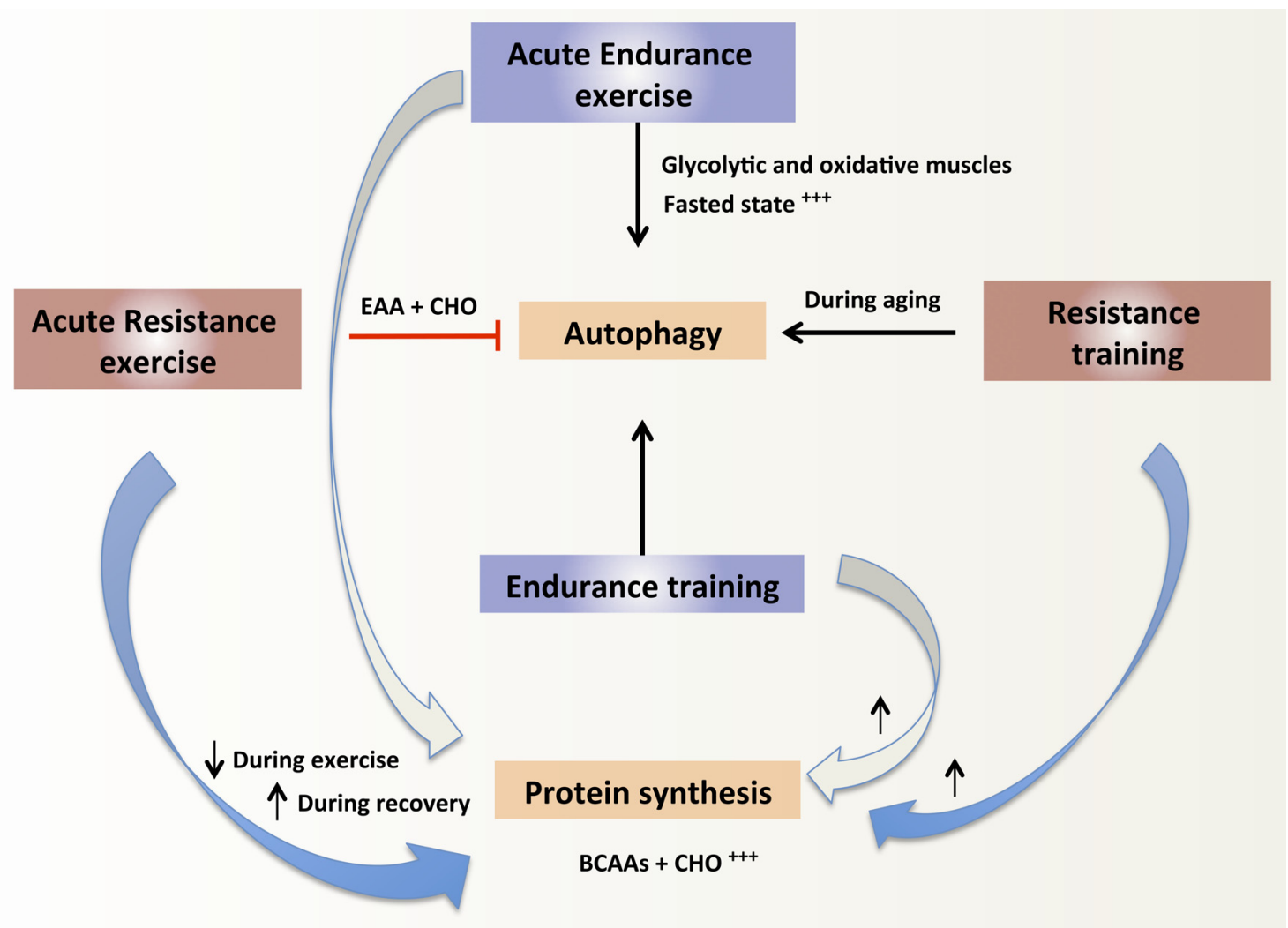

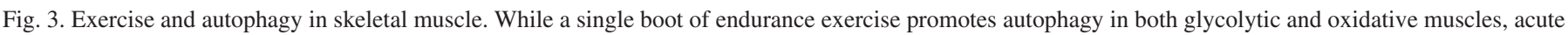

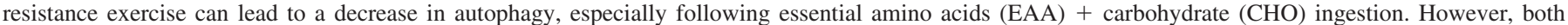

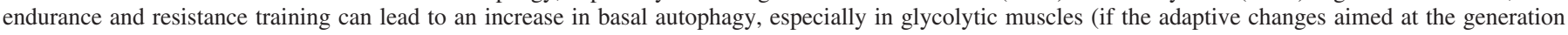

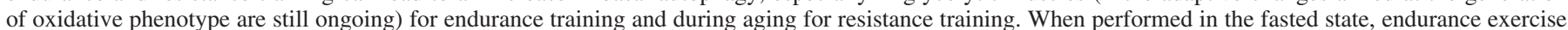

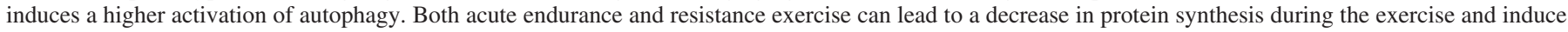

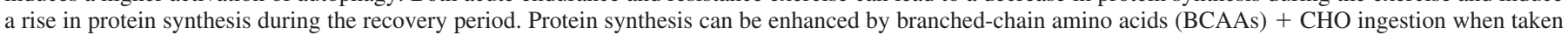
immediately after exercise.

further studies are needed to clarify the involvement of mitophagy not only during exercise, but also the clearance of other important organelles, such as the endoplasmic reticulum (reticulophagy) or ribosomes (ribophagy).

Recently, endoplasmic reticulum stress (ER stress) has been observed through an increase in the expression of the ER stress-induced transcription factor $\mathrm{C} / \mathrm{EBP}$ homologous protein (CHOP), the double-stranded RNA-activated protein kinase (PKR)-like endoplasmic reticulum kinase (PERK), and the $\mathrm{X}$-box binding protein 1 (XBP1s), in response to both ultraendurance (70) and moderate-intensity exercise (61). A consequence of ER stress is the phosphorylation at Ser-51 of the regulatory $\alpha$-subunit of the eukaryotic initiation factor 2 (eIF2) by PERK (49). Accordingly, eIF2 Ser-51 phosphorylation increases during moderate- and high-intensity exercise (61, 107). eIF2 is a heterotrimeric complex that mediates the binding of tRNAmet to the ribosome in a GTP-dependent manner. The phosphorylation of the $\alpha$-subunit of eIF2 at Ser-51 1) results in the stabilization of the eIF2-GDP-eIF2B complex that inhibits the turnover of $\operatorname{eIF} 2 \mathrm{~B}(36), 2)$ promotes Atg5 and LC3B transcription through ATF4 and CHOP (114), and 3) leads to LC3B protein lipidation (76), illustrating that eIF2 phosphorylation both attenuates protein synthesis and promotes autophagy. However, the turnover process of endoplasmic reticulum itself remains to be explored, especially in the context of exercise.
Concerning ribosomes, the pathways of normal and damaged ribosome turnover, especially rRNA decay, have been little explored in skeletal muscle. They warrant further investigation, however, because ribophagy, like mitophagy, may have a quality control function by specifically eliminating incorrectly assembled, nonfunctional, and damaged ribosomes. For example, the impact of chronic exercise on the efficiency of the translational machinery merits exploration, particularly in the context of aging, which is notably characterized by an impairment of contraction-induced skeletal muscle protein synthesis (35). It would also be very helpful to study the impact of exercise according to the fiber typology, as autophagy occurs differently depending on typology (oxidative vs. glycolytic muscle). A recent study (100) showed that Atgs are differently expressed depending on the muscle typology. ULK1, Atg5, and Atg12 are more abundantly expressed in the glycolytic tibialis anterior, extensor digitorum longus, and gastrocnemius plantaris compared with the diaphragm and soleus, whereas the Beclin-1 complex, LC3B, GABARAPL1, BNIP3, and Parkin show a reverse pattern. Interestingly, the latter proteins are required for mitophagy, suggesting greater mitochondrial turnover for oxidative compared with glycolytic fibers.

In summary, the mechanisms of organelle clearance during exercise remain elusive and overly descriptive. Although several studies have indicated that exercise may promote mitochondrial and endoplasmic reticulum stress, the issue of their 
turnover during exercise and the underlying mechanistic events remain to be elucidated, especially for reticulophagy.

Training and autophagy. The role of autophagy in skeletal muscle adaptation to chronic exercise has recently been investigated, especially its role in mitochondrial metabolism and during aging. First, Lira et al. (79) observed higher LC3-II/ LC3-I ratio and LC3-II levels and reduced p62 protein level in oxidative muscles of mice, suggesting that basal level of autophagy is more elevated in oxidative muscles (79). An important point to keep in mind in this study is that endurance training (voluntary running for $4 \mathrm{wk}$ ) increased the level of basal autophagy and the BNIP3-related mitophagy axis, in glycolytic muscles, concomitantly to an increase in mitochondrial biogenesis (79). The oxidative muscles showed only an increase in autophagy protein expression, but without apparent alteration of basal autophagy flux and mitochondrial biogenesis (79). By using a genetic model of augmented mitochondrial content (i.e., muscle-specific PGC- $1 \alpha$ transgenic mice), the authors suggested that, in the context of training, the rise in basal autophagy seems to take place when an oxidative phenotype is reached (79). Thus, the autophagic process may be closely related to the conversion of fibers toward an endurance profile. Consistent with this, Atg6-deficient mice showed a decrease in mitochondrial content along with an attenuation of training-induced improvement in endurance aptitude (79). Thus, autophagy appears to be an essential pathway for skeletal muscle metabolic adaptation to endurance exercise and improvement in aerobic performance. However, in the latter study, training was also able to induce an increase in MHC2a expression, indicating that autophagy is not the only process explaining all of the adaptations to endurance exercise. The rise in autophagy induced by endurance training was also found in another study in which the authors showed that exercise partially counterbalanced the chloroquine-induced inhibition of autophagic flux (62). In sarcopenia, chronic exercise also enhances basal autophagy (72). An attenuation of the autophagy machinery takes place over the course of aging, especially the Beclin-1, Atg7, LC3-II, and LAMP2a levels in both oxidative and glycolytic muscles (72), suggesting a declining ability to eliminate damaged or inefficient organelles. Importantly, both endurance and resistance training are able to reverse the undesirable effects of sarcopenia on the autophagy regulatory proteins $(72,84)$. Similar results have also been reported in older and obese women by Wohlgemuth et al. (152), who found an increase in mRNA levels of LC3B and Atg7, and a tendency for $L A M P 2$, in response to a 6-mo weight loss program combined with moderate-intensity exercise.

Taken together, these studies highlight the likelihood that the autophagy machinery is modulated in response to training (Fig. 3) and mediates the beneficial effects on muscle homeostasis over the course of aging, suggesting promising perspectives in the area of sports medicine. Other studies are needed to determine the optimal training modality to bring about such adaptations in both athletes and patients.

\section{Summary and Future Perspectives}

Over the past several years, significant advances have been made in uncovering the molecular mechanisms underlying skeletal muscle protein turnover in response to exercise, especially the autophagic and mitochondrial turnover pathways that had long been forgotten in this tissue. Autophagy appears to be an essential process to support muscle plasticity in response to exercise. From a general point of view, the autophagy process is necessary to ensure exercise-induced metabolic effects, and potentially health benefits of regular exercise. In acute conditions, although resistance exercise preferentially stimulates protein breakdown by E3 ligases and proteasome system, endurance exercise and the autophagy pathway appear to be closely linked. A single bout of endurance exercise can affect protein turnover markers, especially indexes of autophagic flux when the exercise duration is sufficient, and these adaptations seem to be dependent on the training level. An important point is that autophagy modulation by exercise is linked to the nutritional status since autophagic sensors are modulated by amino acid and glucose availability. In this way, autophagy response is more important when exercise is conducted in the fasted state. Chronic exercise affects the basal level of the autophagy system by increasing the transcription of several Atgs and potentially autophagic flux, especially if the adaptive changes aimed at the generation of oxidative phenotype are ongoing.

However, further studies are needed to better understand the physiological functions of autophagy during exercise, especially the possible involvement of mitophagy and other forms of specific autophagy, like ribophagy and reticulophagy, in training adaptations. As exercise-induced mitophagy could be linked to a better mitochondrial turnover and an improvement of resistance to oxidative stress, we can speculate that ribophagy and reticulophagy could be involved in a better translation efficiency in trained subjects. Nevertheless, additional work is required to confirm these potential roles. These research axes have to be extended to aging models since aging shows a decline in housekeeping and cleaning mechanisms, leading to an accumulation of undesirable components. From a methodological point of view, the mitophagy pathway has been studied only with the quantification of mRNA or protein markers, and this is not sufficient to confirm whether or not this process is really activated during exercise. Also, the numerous descriptive studies on protein turnover and autophagy do not differentiate flux from the proteasome vs. that of the lysosome. Further studies need to be encouraged to clarify the part of each system in protein breakdown in the context of exercise. Another important perspective will be to improve our knowledge on the impact of ergogenic aids on the timing and level of autophagy, since it is now recognized that autophagy flux can be impacted by the nutritional status.

A better comprehension of the exercise-induced adaptive mechanisms in skeletal muscle is important for the training of athletes, and it would also enhance our understanding of disease etiology. With regard to the last point, we also believe it is vital to determine the impact of different training methods because exercise constitutes the best approach to improving or maintaining functional capacities.

\section{ACKNOWLEDGMENTS}

A. M. J. Sanchez thanks the "Cité de l'excellence sportive Sud de France" of Font-Romeu.

\section{GRANTS}

A. M. J. Sanchez was funded by a Meakins-Christie fellowship. 


\section{DISCLOSURES}

No conflicts of interest, financial or otherwise, are declared by the authors.

\section{AUTHOR CONTRIBUTIONS}

Author contributions: A.M.S. conception and design of research; A.M.S. prepared figures; A.M.S. drafted manuscript; A.M.S., H.B., G.P., and R.C. edited and revised manuscript; A.M.S., H.B., G.P., and R.C. approved final version of manuscript.

\section{REFERENCES}

1. Alessi DR, James SR, Downes CP, Holmes AB, Gaffney PRJ, Reese CB, Cohen P. Characterization of a 3-phosphoinositide-dependent protein kinase which phosphorylates and activates protein kinase $\mathrm{B} \alpha$. Curr Biol 7: 261-269, 1997.

2. Alvestrand A, Hagenfeldt L, Merli M, Oureshi A, Eriksson LS. Influence of leucine infusion on intracellular amino acids in humans. Eur J Clin Invest 20: 293-298, 1990.

3. Aschenbach WG, Hirshman MF, Fujii N, Sakamoto K, Howlett KF, Goodyear LJ. Effect of AICAR treatment on glycogen metabolism in skeletal muscle. Diabetes 51: 567-573, 2002.

4. Atherton PJ, Babraj J, Smith K, Singh J, Rennie MJ, Wackerhage H. Selective activation of AMPK-PGC-1alpha or PKB-TSC2-mTOR signaling can explain specific adaptive responses to endurance or resistance traininglike electrical muscle stimulation. FASEB J 19: 786-788, 2005.

5. Baar K, Wende AR, Jones TE, Marison M, Nolte LA, Chen M, Kelly DP, Holloszy JO. Adaptations of skeletal muscle to exercise: rapid increase in the transcriptional coactivator PGC-1. FASEB $J$ 16: 18791886, 2002.

6. Bennet WM, Connacher AA, Scrimgeour CM, Rennie MJ. The effect of amino acid infusion on leg protein turnover assessed by L- $\left[{ }^{15} \mathrm{~N}\right]$ phenylalanine and L- $\left[1-{ }^{13} \mathrm{C}\right]$ leucine exchange. Eur J Clin Invest 20: 41-50, 1990.

7. Bennet WM, Connacher AA, Scrimgeour CM, Smith K, Rennie MJ. Increase in anterior tibialis muscle protein synthesis in healthy man during mixed amino acid infusion: studies of incorporation of $\left[1-{ }^{13} \mathrm{C}\right]$ leucine. Clin Sci Lond Engl (1979) 76: 447-454, 1989.

8. Bergström J, Fürst $\mathbf{P}$, Norée LO, Vinnars E. Intracellular free amino acid concentration in human muscle tissue. J Appl Physiol 36: 693-697, 1974.

9. Biolo G, Tipton KD, Klein S, Wolfe RR. An abundant supply of amino acids enhances the metabolic effect of exercise on muscle protein. Am J Physiol Endocrinol Metab 273: E122-E129, 1997.

10. Bishop DJ, Granata C, Eynon N. Can we optimise the exercise training prescription to maximise improvements in mitochondria function and content? Biochim Biophys Acta 1840: 1266-1275, 2014.

11. Bjørkøy G, Lamark T, Brech A, Outzen H, Perander M, Overvatn A, Stenmark H, Johansen T. p62/SQSTM1 forms protein aggregates degraded by autophagy and has a protective effect on huntingtin-induced cell death. J Cell Biol 171: 603-614, 2005.

12. Blomstrand E, Eliasson J, Karlsson HKR, Köhnke R. Branched-chain amino acids activate key enzymes in protein synthesis after physical exercise. J Nutr 136: 269S-73S, 2006.

13. Bolster DR, Crozier SJ, Kimball SR, Jefferson LS. AMP-activated protein kinase suppresses protein synthesis in rat skeletal muscle through down-regulated mammalian target of rapamycin (mTOR) signaling. $J$ Biol Chem 277: 23977-23980, 2002.

14. Braschi E, Zunino R, McBride HM. MAPL is a new mitochondrial SUMO E3 ligase that regulates mitochondrial fission. EMBO Rep 10: $748-754,2009$

15. Burd NA, Tang JE, Moore DR, Phillips SM. Exercise training and protein metabolism: influences of contraction, protein intake, and sexbased differences. J Appl Physiol (1985) 106: 1692-1701, 2009.

16. Bylund-Fellenius AC, Ojamaa KM, Flaim KE, Li JB, Wassner SJ, Jefferson LS. Protein synthesis versus energy state in contracting muscles of perfused rat hindlimb. Am J Physiol Endocrinol Metab 246: E297-E305, 1984.

17. Carling D, Clarke PR, Zammit VA, Hardie DG. Purification and characterization of the AMP-activated protein kinase. Copurification of acetyl-CoA carboxylase kinase and 3-hydroxy-3-methylglutaryl-CoA reductase kinase activities. Eur J Biochem 186: 129-136, 1989.

18. Carling D, Hardie DG. The substrate and sequence specificity of the AMP-activated protein kinase. Phosphorylation of glycogen synthase and phosphorylase kinase. Biochim Biophys Acta 1012: 81-86, 1989.
19. Carling D, Zammit VA, Hardie DG. A common bicyclic protein kinase cascade inactivates the regulatory enzymes of fatty acid and cholesterol biosynthesis. FEBS Lett 223: 217-222, 1987.

20. Castets P, Lin S, Rion N, Di Fulvio S, Romanino K, Guridi M, Frank S, Tintignac LA, Sinnreich M, Rüegg MA. Sustained activation of mTORC1 in skeletal muscle inhibits constitutive and starvation-induced autophagy and causes a severe, late-onset myopathy. Cell Metab 17: 731-744, 2013.

21. Castro AF, Rebhun JF, Clark GJ, Quilliam LA. Rheb binds tuberous sclerosis complex 2 (TSC2) and promotes S6 kinase activation in a rapamycin- and farnesylation-dependent manner. $J$ Biol Chem 278: 32493-32496, 2003.

22. Clarke BA, Drujan D, Willis MS, Murphy LO, Corpina RA, Burova E, Rakhilin SV, Stitt TN, Patterson C, Latres E, Glass DJ. The E3 ligase MuRF1 degrades myosin heavy chain protein in dexamethasonetreated skeletal muscle. Cell Metab 6: 376-385, 2007.

23. Cohen S, Brault JJ, Gygi SP, Glass DJ, Valenzuela DM, Gartner C, Latres E, Goldberg AL. During muscle atrophy, thick, but not thin, filament components are degraded by MuRF1-dependent ubiquitylation. J Cell Biol 185: 1083-1095, 2009.

24. Cohen S, Zhai B, Gygi SP, Goldberg AL. Ubiquitylation by Trim32 causes coupled loss of desmin, Z-bands, and thin filaments in muscle atrophy. J Cell Biol 198: 575-589, 2012.

25. Csibi A, Cornille K, Leibovitch MP, Poupon A, Tintignac LA, Sanchez AMJ, Leibovitch SA. The translation regulatory subunit eIF3f controls the kinase-dependent mTOR signaling required for muscle differentiation and hypertrophy in mouse. PloS One 5: e8994, 2010.

26. Csibi A, Leibovitch MP, Cornille K, Tintignac LA, Leibovitch SA. MAFbx/Atrogin-1 controls the activity of the initiation factor eIF3-f in skeletal muscle atrophy by targeting multiple C-terminal lysines. J Biol Chem 284: 4413-4421, 2009.

27. Davies KJ, Quintanilha AT, Brooks GA, Packer L. Free radicals and tissue damage produced by exercise. Biochem Biophys Res Commun 107: 1198-1205, 1982.

28. Dreyer HC, Fujita S, Cadenas JG, Chinkes DL, Volpi E, Rasmussen BB. Resistance exercise increases AMPK activity and reduces 4E-BP1 phosphorylation and protein synthesis in human skeletal muscle. $J$ Physiol 576: 613-624, 2006.

29. Drummond MJ, Fry CS, Glynn EL, Dreyer HC, Dhanani S, Timmerman KL, Volpi E, Rasmussen BB. Rapamycin administration in humans blocks the contraction-induced increase in skeletal muscle protein synthesis. J Physiol 587: 1535-1546, 2009.

30. Egan D, Kim J, Shaw RJ, Guan KL. The autophagy initiating kinase ULK1 is regulated via opposing phosphorylation by AMPK and mTOR. Autophagy 7: 643-644, 2011.

31. Egan DF, Shackelford DB, Mihaylova MM, Gelino S, Kohnz RA, Mair W, Vasquez DS, Joshi A, Gwinn DM, Taylor R, Asara JM, Fitzpatrick J, Dillin A, Viollet B, Kundu M, Hansen M, Shaw RJ. Phosphorylation of ULK1 (hATG1) by AMP-activated protein kinase connects energy sensing to mitophagy. Science 331: 456-461, 2011.

32. Esbjörnsson M, Rundqvist HC, Mascher H, Österlund T, Rooyackers O, Blomstrand E, Jansson E. Sprint exercise enhances skeletal muscle p70S6k phosphorylation and more so in women than in men. Acta Physiol Oxf Engl 205: 411-422, 2012.

33. Ferraro E, Giammarioli AM, Chiandotto S, Spoletini I, Rosano G. Exercise-induced skeletal muscle remodeling and metabolic adaptation: redox signaling and role of autophagy. Antioxid Redox Signal 21: $154-176,2014$.

34. Frias MA, Thoreen CC, Jaffe JD, Schroder W, Sculley T, Carr SA, Sabatini DM. mSin1 is necessary for Akt/PKB phosphorylation, and its isoforms define three distinct mTORC2s. Curr Biol 16: 1865-1870, 2006.

35. Fry CS, Drummond MJ, Glynn EL, Dickinson JM, Gundermann DM, Timmerman KL, Walker DK, Dhanani S, Volpi E, Rasmussen BB. Aging impairs contraction-induced human skeletal muscle mTORC1 signaling and protein synthesis. Skelet Muscle 1: 11, 2011.

36. Fry CS, Drummond MJ, Glynn EL, Dickinson JM, Gundermann DM, Timmerman KL, Walker DK, Volpi E, Rasmussen BB. Skeletal muscle autophagy and protein breakdown following resistance exercise are similar in younger and older adults. J Gerontol A Biol Sci Med Sci 68: 599-607, 2013.

37. Garami A, Zwartkruis FJT, Nobukuni T, Joaquin M, Roccio M, Stocker H, Kozma SC, Hafen E, Bos JL, Thomas G. Insulin activation of Rheb, a mediator of mTOR/S6K/4E-BP signaling, is inhibited by TSC1 and 2. Mol Cell 11: 1457-1466, 2003. 
38. Garton AJ, Campbell DG, Carling D, Hardie DG, Colbran RJ, Yeaman SJ. Phosphorylation of bovine hormone-sensitive lipase by the AMP-activated protein kinase. A possible antilipolytic mechanism. Eur J Biochem 179: 249-254, 1989.

39. Ghislat G, Patron M, Rizzuto R, Knecht E. Withdrawal of essential amino acids increases autophagy by a pathway involving $\mathrm{Ca}^{2+} /$ calmodulin-dependent kinase kinase- $\beta$ (CaMKK- $\beta$ ). J Biol Chem 287: $38625-$ 38636, 2012

40. Gibala MJ. Regulation of skeletal muscle amino acid metabolism during exercise. Int J Sport Nutr Exerc Metab 11: 87-108, 2001.

41. Glynn EL, Fry CS, Drummond MJ, Dreyer HC, Dhanani S, Volpi E, Rasmussen BB. Muscle protein breakdown has a minor role in the protein anabolic response to essential amino acid and carbohydrate intake following resistance exercise. Am J Physiol Regul Integr Comp Physiol 299: R533-R540, 2010.

42. Gollnick PD, King DW. Effect of exercise and training on mitochondria of rat skeletal muscle. Am J Physiol 216: 1502-1509, 1969.

43. Goodman CA, Mayhew DL, Hornberger TA. Recent progress toward understanding the molecular mechanisms that regulate skeletal muscle mass. Cell Signal 23: 1896-1906, 2011

44. Goto M, Terada S, Kato M, Katoh M, Yokozeki T, Tabata I, Shimokawa T. cDNA Cloning and mRNA analysis of PGC-1 in epitrochlearis muscle in swimming-exercised rats. Biochem Biophys Res Commun 274: 350-354, 2000.

45. Grumati P, Coletto L, Schiavinato A, Castagnaro S, Bertaggia E, Sandri M, Bonaldo P. Physical exercise stimulates autophagy in normal skeletal muscles but is detrimental for collagen VI-deficient muscles. Autophagy 7: 1415-1423, 2011

46. Gwinn DM, Shackelford DB, Egan DF, Mihaylova MM, Mery A, Vasquez DS, Turk BE, Shaw RJ. AMPK phosphorylation of raptor mediates a metabolic checkpoint. Mol Cell 30: 214-226, 2008.

47. Haghighat A, Mader S, Pause A, Sonenberg N. Repression of capdependent translation by 4E-binding protein 1: competition with $\mathrm{p} 220$ for binding to eukaryotic initiation factor-4E. EMBO J 14: 5701-5709, 1995.

48. Hara K, Yonezawa K, Kozlowski MT, Sugimoto T, Andrabi K, Weng QP, Kasuga M, Nishimoto I, Avruch J. Regulation of eIF-4E BP1 phosphorylation by mTOR. J Biol Chem 272: 26457-26463, 1997.

49. Harding HP, Novoa I, Zhang Y, Zeng H, Wek R, Schapira M, Ron D. Regulated translation initiation controls stress-induced gene expression in mammalian cells. Mol Cell 6: 1099-1108, 2000.

50. He C, Bassik MC, Moresi V, Sun K, Wei Y, Zou Z, An Z, Loh J, Fisher J, Sun Q, Korsmeyer S, Packer M, May HI, Hill JA, Virgin HW, Gilpin C, Xiao G, Bassel-Duby R, Scherer PE, Levine B. Exercise-induced BCL2-regulated autophagy is required for muscle glucose homeostasis. Nature 481: 511-515, 2012.

51. Hishiya A, Iemura S, Natsume T, Takayama S, Ikeda K, Watanabe K. A novel ubiquitin-binding protein ZNF216 functioning in muscle atrophy. EMBO J 25: 554-564, 2006.

52. Holz MK, Ballif BA, Gygi SP, Blenis J. mTOR and S6K1 mediate assembly of the translation preinitiation complex through dynamic protein interchange and ordered phosphorylation events. Cell 123: 569-580, 2005.

53. Hornberger TA, Chien S. Mechanical stimuli and nutrients regulate rapamycin-sensitive signaling through distinct mechanisms in skeletal muscle. J Cell Biochem 97: 1207-1216, 2006.

54. Hornberger TA, Chu WK, Mak YW, Hsiung JW, Huang SA, Chien S. The role of phospholipase D and phosphatidic acid in the mechanical activation of mTOR signaling in skeletal muscle. Proc Natl Acad Sci USA 103: 4741-4746, 2006.

55. Hornberger TA, Stuppard R, Conley KE, Fedele MJ, Fiorotto ML, Chin ER, Esser KA. Mechanical stimuli regulate rapamycin-sensitive signalling by a phosphoinositide 3-kinase-, protein kinase B- and growth factor-independent mechanism. Biochem J 380: 795-804, 2004.

56. Huynh KK, Eskelinen EL, Scott CC, Malevanets A, Saftig P, Grinstein S. LAMP proteins are required for fusion of lysosomes with phagosomes. EMBO J 26: 313-324, 2007.

57. Inoki K, Zhu T, Guan KL. TSC2 mediates cellular energy response to control cell growth and survival. Cell 115: 577-590, 2003.

58. Jamart C, Benoit N, Raymackers JM, Kim HJ, Kim CK, Francaux M. Autophagy-related and autophagy-regulatory genes are induced in human muscle after ultraendurance exercise. Eur J Appl Physiol 112: 3173-3177, 2012.

59. Jamart C, Francaux M, Millet GY, Deldicque L, Frère D, Féasson L. Modulation of autophagy and ubiquitin-proteasome pathways during ultra-endurance running. J Appl Physiol (1985) 112: 1529-1537, 2012.
60. Jamart C, Gomes AV, Dewey S, Deldicque L, Raymackers JM, Francaux M. Regulation of ubiquitin-proteasome and autophagy pathways after acute LPS and epoxomicin administration in mice. $B M C$ Musculoskelet Disord 15: 166, 2014.

61. Jamart C, Naslain D, Gilson H, Francaux M. Higher activation of autophagy in skeletal muscle of mice during endurance exercise in the fasted state. Am J Physiol Endocrinol Metab 305: E964-E974, 2013.

62. Jiang D, Chen K, Lu X, Gao HJ, Qin ZH, Lin F. Exercise ameliorates the detrimental effect of chloroquine on skeletal muscles in mice via restoring autophagy flux. Acta Pharmacol Sin 35: 135-142, 2014.

63. Jogo M, Shiraishi S, Tamura T. Identification of MAFbx as a myogenin-engaged F-box protein in SCF ubiquitin ligase. FEBS Lett 583: 2715-2719, 2009.

64. Kabeya Y, Mizushima N, Ueno T, Yamamoto A, Kirisako T, Noda T, Kominami E, Ohsumi Y, Yoshimori T. LC3, a mammalian homologue of yeast Apg8p, is localized in autophagosome membranes after processing. EMBO J 19: 5720-5728, 2000.

65. Kamada Y, Funakoshi T, Shintani T, Nagano K, Ohsumi M, Ohsumi Y. Tor-mediated induction of autophagy via an Apg1 protein kinase complex. J Cell Biol 150: 1507-1513, 2000.

66. Kamei Y, Miura S, Suzuki M, Kai Y, Mizukami J, Taniguchi T, Mochida K, Hata T, Matsuda J, Aburatani H, Nishino I, Ezaki O. Skeletal muscle FOXO1 (FKHR) transgenic mice have less skeletal muscle mass, down-regulated type I (slow twitch/red muscle) fiber genes, and impaired glycemic control. J Biol Chem 279: 41114-41123, 2004.

67. Kihara A, Kabeya Y, Ohsumi Y, Yoshimori T. Beclin-phosphatidylinositol 3-kinase complex functions at the trans-Golgi network. EMBO Rep 2: 330-335, 2001.

68. Kim DH, Sarbassov DD, Ali SM, King JE, Latek RR, ErdjumentBromage H, Tempst P, Sabatini DM. mTOR interacts with raptor to form a nutrient-sensitive complex that signals to the cell growth machinery. Cell 110: 163-175, 2002.

69. Kim DH, Sarbassov DD, Ali SM, Latek RR, Guntur KVP, Erdjument-Bromage H, Tempst P, Sabatini DM. G $\beta$ L, a positive regulator of the rapamycin-sensitive pathway required for the nutrient-sensitive interaction between raptor and mTOR. Mol Cell 11: 895-904, 2003.

70. Kim HJ, Jamart C, Deldicque L, An G, Lee YH, Kim CK, Raymackers J, Francaux M. Endoplasmic reticulum stress markers and ubiquitinproteasome pathway activity in response to a $200-\mathrm{km}$ run. Med Sci Sports Exerc 43: 18-25, 2011.

71. Kim J, Kundu M, Viollet B, Guan KL. AMPK and mTOR regulate autophagy through direct phosphorylation of Ulk1. Nat Cell Biol 13: 132-141, 2011.

72. Kim YA, Kim YS, Oh SL, Kim HJ, Song W. Autophagic response to exercise training in skeletal muscle with age. J Physiol Biochem 69: 697-705, 2013.

73. Kim YA, Kim YS, Song W. Autophagic response to a single bout of moderate exercise in murine skeletal muscle. J Physiol Biochem 68: 229-235, 2012

74. Klionsky DJ, .Guidelines for the use and interpretation of assays for monitoring autophagy. Autophagy 8: 445-544, 2012.

75. Kondapalli C, Kazlauskaite A, Zhang N, Woodroof HI, Campbell DG, Gourlay R, Burchell L, Walden H, Macartney TJ, Deak M, Knebel A, Alessi DR, Muqit MMK. PINK1 is activated by mitochondrial membrane potential depolarization and stimulates Parkin E3 ligase activity by phosphorylating serine 65. Open Biol 2: 120080, 2012.

76. Kouroku Y, Fujita E, Tanida I, Ueno T, Isoai A, Kumagai H, Ogawa S, Kaufman RJ, Kominami E, Momoi T. ER stress (PERK/eIF2 $\alpha$ phosphorylation) mediates the polyglutamine-induced LC3 conversion, an essential step for autophagy formation. Cell Death Differ 14: 230 239, 2007

77. Lee JW, Park S, Takahashi Y, Wang HG. The association of AMPK with ULK1 regulates autophagy. PloS One 5: e15394, 2010.

78. Leeuwenburgh C, Hansen PA, Holloszy JO, Heinecke JW. Hydroxyl radical generation during exercise increases mitochondrial protein oxidation and levels of urinary dityrosine. Free Radic Biol Med 27: 186$192,1999$.

79. Lira VA, Okutsu M, Zhang M, Greene NP, Laker RC, Breen DS, Hoehn KL, Yan Z. Autophagy is required for exercise training-induced skeletal muscle adaptation and improvement of physical performance. FASEB J 27: 4184-4193, 2013.

80. Loewith R, Jacinto E, Wullschleger S, Lorberg A, Crespo JL, Bonenfant D, Oppliger W, Jenoe P, Hall MN. Two TOR complexes, 
only one of which is rapamycin sensitive, have distinct roles in cell growth control. Mol Cell 10: 457-468, 2002.

81. Löffler AS, Alers S, Dieterle AM, Keppeler H, Franz-Wachtel M, Kundu M, Campbell DG, Wesselborg S, Alessi DR, Stork B. Ulk1mediated phosphorylation of AMPK constitutes a negative regulatory feedback loop. Autophagy 7: 696-706, 2011.

82. Lokireddy S, Wijesoma IW, Teng S, Bonala S, Gluckman PD, McFarlane C, Sharma M, Kambadur R. The ubiquitin ligase Mul1 induces mitophagy in skeletal muscle in response to muscle-wasting stimuli. Cell Metab 16: 613-624, 2012.

83. Lundberg TR, Fernandez-Gonzalo R, Norrbom J, Fischer H, Tesch PA, Gustafsson T. Truncated splice variant PGC- $1 \alpha 4$ is not associated with exercise-induced human muscle hypertrophy. Acta Physiol. Oxf. Engl. In press.

84. Luo L, Lu AM, Wang Y, Hong A, Chen Y, Hu J, Li X, Qin ZH. Chronic resistance training activates autophagy and reduces apoptosis of muscle cells by modulating IGF-1 and its receptors, Akt/mTOR and Akt/FOXO3a signaling in aged rats. Exp Gerontol 48: 427-436, 2013.

85. Mackenzie MG, Hamilton DL, Murray JT, Baar K. mVps34 is activated by an acute bout of resistance exercise. Biochem Soc Trans 35: 1314-1316, 2007.

86. MacKenzie MG, Hamilton DL, Murray JT, Taylor PM, Baar K. $\mathrm{mVps} 34$ is activated following high-resistance contractions. $J$ Physiol 587: 253-260, 2009.

87. Mammucari C, Milan G, Romanello V, Masiero E, Rudolf R, Del Piccolo P, Burden SJ, Di Lisi R, Sandri C, Zhao J, Goldberg AL, Schiaffino S, Sandri M. FoxO3 controls autophagy in skeletal muscle in vivo. Cell Metab 6: 458-471, 2007.

88. Marsin AS, Bertrand L, Rider MH, Deprez J, Beauloye C, Vincent MF, Van den Berghe G, Carling D, Hue L. Phosphorylation and activation of heart PFK-2 by AMPK has a role in the stimulation of glycolysis during ischaemia. Curr Biol 10: 1247-1255, 2000.

89. Mascher H, Andersson H, Nilsson PA, Ekblom B, Blomstrand E. Changes in signalling pathways regulating protein synthesis in human muscle in the recovery period after endurance exercise. Acta Physiol Oxf Engl 191: 67-75, 2007.

90. Mascher H, Ekblom B, Rooyackers O, Blomstrand E. Enhanced rates of muscle protein synthesis and elevated mTOR signalling following endurance exercise in human subjects. Acta Physiol Oxf Engl 202: 175-184, 2011.

91. Masiero E, Agatea L, Mammucari C, Blaauw B, Loro E, Komatsu M, Metzger D, Reggiani C, Schiaffino S, Sandri M. Autophagy is required to maintain muscle mass. Cell Metab 10: 507-515, 2009.

92. Matsuda N, Sato S, Shiba K, Okatsu K, Saisho K, Gautier CA, Sou YS, Saiki S, Kawajiri S, Sato F, Kimura M, Komatsu M, Hattori N, Tanaka K. PINK1 stabilized by mitochondrial depolarization recruits Parkin to damaged mitochondria and activates latent Parkin for mitophagy. J Cell Biol 189: 211-221, 2010.

93. Matsuura A, Tsukada M, Wada Y, Ohsumi Y. Apg1p, a novel protein kinase required for the autophagic process in Saccharomyces cerevisiae. Gene 192: 245-250, 1997.

94. McConell GK, Lee-Young RS, Chen ZP, Stepto NK, Huynh NN, Stephens TJ, Canny BJ, Kemp BE. Short-term exercise training in humans reduces AMPK signalling during prolonged exercise independent of muscle glycogen. J Physiol 568: 665-676, 2005.

95. McPherron AC, Lawler AM, Lee SJ. Regulation of skeletal muscle mass in mice by a new TGF- $\beta$ superfamily member. Nature 387: 83-90, 1997.

96. Merrill GF, Kurth EJ, Hardie DG, Winder WW. AICA riboside increases AMP-activated protein kinase, fatty acid oxidation, and glucose uptake in rat muscle. Am J Physiol Endocrinol Metab 273: E1107E1112, 1997.

97. Miyazaki M, McCarthy JJ, Fedele MJ, Esser KA. Early activation of mTORC1 signalling in response to mechanical overload is independent of phosphoinositide 3-kinase/Akt signalling. J Physiol 589: 1831-1846, 2011.

98. Mizushima N, Noda T, Ohsumi Y. Apg16p is required for the function of the Apg12p-Apg5p conjugate in the yeast autophagy pathway. EMBO J 18: 3888-3896, 1999.

99. Mizushima N, Sugita H, Yoshimori T, Ohsumi Y. A new protein conjugation system in human. The counterpart of the yeast Apg12p conjugation system essential for autophagy. J Biol Chem 273: 3388933892, 1998

100. Mofarrahi M, Guo Y, Haspel JA, Choi AM, Davis EC, Gouspillou G, Hepple RT, Godin R, Burelle Y, Hussain SN. Autophagic flux and oxidative capacity of skeletal muscles during acute starvation. Autophagy 9 , 2013.

101. Mofarrahi M, Sigala I, Guo Y, Godin R, Davis EC, Petrof B, Sandri M, Burelle Y, Hussain SNA. Autophagy and skeletal muscles in sepsis. PloS One 7: e47265, 2012.

102. Nader GA, Esser KA. Intracellular signaling specificity in skeletal muscle in response to different modes of exercise. J Appl Physiol (1985) 90: 1936-1942, 2001.

103. Nair KS, Schwartz RG, Welle S. Leucine as a regulator of whole body and skeletal muscle protein metabolism in humans. Am J Physiol Endocrinol Metab 263: E928-E934, 1992.

104. Nakashima K, Yakabe Y. AMPK activation stimulates myofibrillar protein degradation and expression of atrophy-related ubiquitin ligases by increasing FOXO transcription factors in $\mathrm{C} 2 \mathrm{C} 12$ myotubes. Biosci Biotechnol Biochem 71: 1650-1656, 2007.

105. Nakatogawa H, Ichimura Y, Ohsumi Y. Atg8, a ubiquitin-like protein required for autophagosome formation, mediates membrane tethering and hemifusion. Cell 130: 165-178, 2007.

106. Novak I, Kirkin V, McEwan DG, Zhang J, Wild P, Rozenknop A, Rogov V, Löhr F, Popovic D, Occhipinti A, Reichert AS, Terzic J, Dötsch V, Ney PA, Dikic I. Nix is a selective autophagy receptor for mitochondrial clearance. EMBO Rep 11: 45-51, 2010.

107. Pagano AF, Py G, Bernardi H, Candau RB, Sanchez AMJ. Autophagy and protein turnover signaling in slow-twitch muscle during exercise. Med Sci Sports Exerc 46: 1314-1325, 2014.

108. Pankiv S, Clausen TH, Lamark T, Brech A, Bruun JA, Outzen H, Øvervatn A, Bjørkøy G, Johansen T. p62/SQSTM1 binds directly to Atg8/LC3 to facilitate degradation of ubiquitinated protein aggregates by autophagy. J Biol Chem 282: 24131-24145, 2007.

109. Pruznak AM, Kazi AA, Frost RA, Vary TC, Lang CH. Activation of AMP-activated protein kinase by 5-aminoimidazole-4-carboxamide-1- $\beta$ D-ribonucleoside prevents leucine-stimulated protein synthesis in rat skeletal muscle. J Nutr 138: 1887-1894, 2008.

110. Pullen N, Dennis PB, Andjelkovic M, Dufner A, Kozma SC, Hemmings BA, Thomas G. Phosphorylation and activation of p70s6k by PDK1. Science 279: 707-710, 1998.

111. Rahman M, Mofarrahi M, Kristof AS, Nkengfac B, Harel S, Hussain SNA. Reactive oxygen species regulation of autophagy in skeletal muscles. Antioxid Redox Signal 20: 443-459, 2014.

112. Rennie MJ, Tipton KD. Protein and amino acid metabolism during and after exercise and the effects of nutrition. Аnnu Rev Nutr 20: 457-483, 2000.

113. Romanov J, Walczak M, Ibiricu I, Schüchner S, Ogris E, Kraft C, Martens S. Mechanism and functions of membrane binding by the Atg5-Atg12/Atg16 complex during autophagosome formation. EMBO J 31: 4304-4317, 2012.

114. Rouschop KMA, van den Beucken T, Dubois L, Niessen H, Bussink J, Savelkouls K, Keulers T, Mujcic H, Landuyt W, Voncken JW, Lambin P, van der Kogel AJ, Koritzinsky M, Wouters BG. The unfolded protein response protects human tumor cells during hypoxia through regulation of the autophagy genes MAP1LC3B and ATG5. $J$ Clin Invest 120: 127-141, 2010.

115. Ruas JL, White JP, Rao RR, Kleiner S, Brannan KT, Harrison BC, Greene NP, Wu J, Estall JL, Irving BA, Lanza IR, Rasbach KA, Okutsu M, Nair KS, Yan Z, Leinwand LA, Spiegelman BM. A PGC-1 $\alpha$ isoform induced by resistance training regulates skeletal muscle hypertrophy. Cell 151: 1319-1331, 2012.

116. Russell RC, Tian Y, Yuan H, Park HW, Chang YY, Kim J, Kim H, Neufeld TP, Dillin A, Guan KL. ULK1 induces autophagy by phosphorylating Beclin-1 and activating VPS34 lipid kinase. Nat Cell Biol 15: 741-750, 2013.

117. Sahlin K, Shabalina IG, Mattsson CM, Bakkman L, Fernström M, Rozhdestvenskaya Z, Enqvist JK, Nedergaard J, Ekblom B, Tonkonogi M. Ultraendurance exercise increases the production of reactive oxygen species in isolated mitochondria from human skeletal muscle. J Appl Physiol 108: 780-787, 2010.

118. Saitoh M, Pullen N, Brennan P, Cantrell D, Dennis PB, Thomas G. Regulation of an activated S6 kinase 1 variant reveals a novel mammalian target of rapamycin phosphorylation site. J Biol Chem 277: 2010420112, 2002.

119. Sakai Y, Iwamura Y, Hayashi J, Yamamoto N, Ohkoshi N, Nagata H. Acute exercise causes mitochondrial DNA deletion in rat skeletal muscle. Muscle Nerve 22: 258-261, 1999. 
120. Saleem A, Carter HN, Hood DA. p53 is necessary for the adaptive changes in cellular milieu subsequent to an acute bout of endurance exercise. Am J Physiol Cell Physiol 306: C241-C249, 2014.

121. Salminen A, Vihko V. Autophagic response to strenuous exercise in mouse skeletal muscle fibers. Virchows Arch B Cell Pathol Incl Mol Pathol 45: 97-106, 1984.

122. Salt IP, Johnson G, Ashcroft SJ, Hardie DG. AMP-activated protein kinase is activated by low glucose in cell lines derived from pancreatic beta cells, and may regulate insulin release. Biochem J 335: 533-539, 1998.

123. Sancak Y, Peterson TR, Shaul YD, Lindquist RA, Thoreen CC, Bar-Peled L, Sabatini DM. The Rag GTPases bind raptor and mediate amino acid signaling to mTORC1. Science 320: 1496-1501, 2008.

124. Sanchez AMJ, Candau RB, Bernardi H. FoxO transcription factors: their roles in the maintenance of skeletal muscle homeostasis. Cell Mol Life Sci 71: 1657-1671, 2014

125. Sanchez AMJ, Candau RB, Csibi A, Pagano AF, Raibon A, Bernardi H. The role of AMP-activated protein kinase in the coordination of skeletal muscle turnover and energy homeostasis. Am J Physiol Cell Physiol 303: C475-C485, 2012.

126. Sanchez AMJ, Csibi A, Raibon A, Cornille K, Gay S, Bernardi H, Candau R. AMPK promotes skeletal muscle autophagy through activation of forkhead FoxO3a and interaction with Ulk1. J Cell Biochem 113: 695-710, 2012.

127. Sanchez AMJ, Csibi A, Raibon A, Docquier A, Lagirand-Cantaloube J, Leibovitch MP, Leibovitch SA, Bernardi H. eIF3f: a central regulator of the antagonism atrophy/hypertrophy in skeletal muscle. Int $J$ Biochem Cell Biol 45: 2158-2162, 2013.

128. Sandri M, Sandri C, Gilbert A, Skurk C, Calabria E, Picard A, Walsh K, Schiaffino S, Lecker SH, Goldberg AL. Foxo transcription factors induce the atrophy-related ubiquitin ligase atrogin-1 and cause skeletal muscle atrophy. Cell 117: 399-412, 2004

129. Sandri M. Autophagy in health and disease. 3. Involvement of autophagy in muscle atrophy. Am J Physiol Cell Physiol 298: C1291C1297, 2010.

130. Sarbassov DD, Ali SM, Kim DH, Guertin DA, Latek RR, ErdjumentBromage H, Tempst P, Sabatini DM. Rictor, a novel binding partner of mTOR, defines a rapamycin-insensitive and raptor-independent pathway that regulates the cytoskeleton. Curr Biol 14: 1296-1302, 2004.

131. Sarbassov DD, Guertin DA, Ali SM, Sabatini DM. Phosphorylation and regulation of Akt/PKB by the rictor-mTOR complex. Science 307: 1098-1101, 2005.

132. Spangenburg EE, Le Roith D, Ward CW, Bodine SC. A functional insulin-like growth factor receptor is not necessary for load-induced skeletal muscle hypertrophy. J Physiol 586: 283-291, 2008

133. Stitt TN, Drujan D, Clarke BA, Panaro F, Timofeyva Y, Kline WO, Gonzalez M, Yancopoulos GD, Glass DJ. The IGF-1/PI3K/Akt pathway prevents expression of muscle atrophy-induced ubiquitin ligases by inhibiting FOXO transcription factors. Mol Cell 14: 395-403, 2004.

134. Stokoe D, Stephens LR, Copeland T, Gaffney PR, Reese CB, Painter GF, Holmes AB, McCormick F, Hawkins PT. Dual role of phosphatidylinositol-3,4,5-trisphosphate in the activation of protein kinase B. Science 277: 567-570, 1997.

135. Suzuki K, Kirisako T, Kamada Y, Mizushima N, Noda T, Ohsumi Y. The pre-autophagosomal structure organized by concerted functions of APG genes is essential for autophagosome formation. EMBO $J 20$ : 5971-5981, 2001.

136. Tam BT, Siu PM. Autophagic cellular responses to physical exercise in skeletal muscle. Sports Med Auckl NZ 44: 625-640, 2014.

137. Tesch PA. Skeletal muscle adaptations consequent to long-term heavy resistance exercise. Med Sci Sports Exerc 20: S132-S134, 1988.

138. Tidball JG. Mechanical signal transduction in skeletal muscle growth and adaptation. J Appl Physiol 98: 1900-1908, 2005.

139. Tintignac LA, Lagirand J, Batonnet S, Sirri V, Leibovitch MP, Leibovitch SA. Degradation of MyoD mediated by the SCF (MAFbx) ubiquitin ligase. J Biol Chem 280: 2847-2856, 2005.

140. Tipton KD, Ferrando AA, Phillips SM, David Doyle J, Wolfe RR. Postexercise net protein synthesis in human muscle from orally administered amino acids. Am J Physiol Endocrinol Metab 276: E628-E634, 1999.

141. Twig G, Elorza A, Molina AJA, Mohamed H, Wikstrom JD, Walzer G, Stiles L, Haigh SE, Katz S, Las G, Alroy J, Wu M, Py BF, Yuan J, Deeney JT, Corkey BE, Shirihai OS. Fission and selective fusion govern mitochondrial segregation and elimination by autophagy. EMBO J 27: 433-446, 2008 .
142. Vainshtein A, Grumati P, Sandri M, Bonaldo P. Skeletal muscle, autophagy, and physical activity: the ménage à trois of metabolic regulation in health and disease. J Mol Med 92: 127-137, 2014.

143. Vander Haar E, Lee SI, Bandhakavi S, Griffin TJ, Kim DH. Insulin signalling to mTOR mediated by the Akt/PKB substrate PRAS40. Nat Cell Biol 9: 316-323, 2007.

144. Vavvas D, Apazidis A, Saha AK, Gamble J, Patel A, Kemp BE, Witters LA, Ruderman NB. Contraction-induced changes in acetylCoA carboxylase and 5'-AMP-activated kinase in skeletal muscle. J Biol Chem 272: 13255-13261, 1997.

145. Vissing K, McGee SL, Farup J, Kjølhede T, Vendelbo MH, Jessen N. Differentiated mTOR but not AMPK signaling after strength vs endurance exercise in training-accustomed individuals. Scand J Med Sci Sports 23: 355-366, 2013.

146. Vives-Bauza C, Zhou C, Huang Y, Cui M, de Vries RLA, Kim J, May J, Tocilescu MA, Liu W, Ko HS, Magrané J, Moore DJ, Dawson VL, Grailhe R, Dawson TM, Li C, Tieu K, Przedborski S. PINK1dependent recruitment of Parkin to mitochondria in mitophagy. Proc Natl Acad Sci USA 107: 378-383, 2010.

147. Waddell DS, Baehr LM, van den Brandt J, Johnsen SA, Reichardt HM, Furlow JD, Bodine SC. The glucocorticoid receptor and FOXO1 synergistically activate the skeletal muscle atrophy-associated MuRF1 gene. Am J Physiol Endocrinol Metab 295: E785-E797, 2008.

148. Wagenmakers AJ. Muscle amino acid metabolism at rest and during exercise: role in human physiology and metabolism. Exerc Sport Sci Rev 26: 287-314, 1998.

149. West DWD, Kujbida GW, Moore DR, Atherton P, Burd NA, Padzik JP, De Lisio M, Tang JE, Parise G, Rennie MJ, Baker SK, Phillips SM. Resistance exercise-induced increases in putative anabolic hormones do not enhance muscle protein synthesis or intracellular signalling in young men. $J$ Physiol 587: 5239-5247, 2009.

150. Winder WW, Hardie DG. Inactivation of acetyl-CoA carboxylase and activation of AMP-activated protein kinase in muscle during exercise. Am J Physiol Endocrinol Metab 270: E299-E304, 1996.

151. Winder WW, Wilson HA, Hardie DG, Rasmussen BB, Hutber CA, Call GB, Clayton RD, Conley LM, Yoon S, Zhou B. Phosphorylation of rat muscle acetyl-CoA carboxylase by AMP-activated protein kinase and protein kinase A. J Appl Physiol (1985) 82: 219-225, 1997.

152. Wohlgemuth SE, Lees HA, Marzetti E, Manini TM, Aranda JM, Daniels MJ, Pahor M, Perri MG, Leeuwenburgh C, Anton SD. An exploratory analysis of the effects of a weight loss plus exercise program on cellular quality control mechanisms in older overweight women. Rejuvenation Res 14: 315-324, 2011.

153. Wojtaszewski JF, Nielsen P, Hansen BF, Richter EA, Kiens B. Isoformspecific and exercise intensity-dependent activation of 5'-AMP-activated protein kinase in human skeletal muscle. $J$ Physiol 528: 221-226, 2000.

154. Wu Z, Puigserver P, Andersson U, Zhang C, Adelmant G, Mootha V, Troy A, Cinti S, Lowell B, Scarpulla RC, Spiegelman BM. Mechanisms controlling mitochondrial biogenesis and respiration through the thermogenic coactivator PGC-1. Cell 98: 115-124, 1999.

155. Ydfors M, Fischer H, Mascher H, Blomstrand E, Norrbom J, Gustafsson T. The truncated splice variants, NT-PGC- $1 \alpha$ and PGC- $1 \alpha 4$, increase with both endurance and resistance exercise in human skeletal muscle. Physiol Rep 1: e00140, 2013.

156. Yoon MS, Du G, Backer JM, Frohman MA, Chen J. Class III PI-3-kinase activates phospholipase D in an amino acid-sensing mTORC1 pathway. J Cell Biol 195: 435-447, 2011.

157. You JS, Lincoln HC, Kim CR, Frey JW, Goodman CA, Zhong XP, Hornberger TA. The role of diacylglycerol kinase $\zeta$ and phosphatidic acid in the mechanical activation of mammalian target of rapamycin (mTOR) signaling and skeletal muscle hypertrophy. J Biol Chem 289: 1551-1563, 2014.

158. You JS, Frey JW, Hornberger TA. Mechanical stimulation induces mTOR signaling via an ERK-independent mechanism: implications for a direct activation of mTOR by phosphatidic acid. PLoS One 7: e47258, 2012.

159. Youle RJ, Narendra DP. Mechanisms of mitophagy. Nat Rev Mol Cell Biol 12: 9-14, 2011

160. Youtani T, Tomoo K, Ishida T, Miyoshi H, Miura K. Regulation of human eIF4E by 4E-BP1: binding analysis using surface plasmon resonance. IUBMB Life 49: 27-31, 2000.

161. Zhao J, Brault JJ, Schild A, Cao P, Sandri M, Schiaffino S, Lecker SH, Goldberg AL. FoxO3 coordinately activates protein degradation by the autophagic/lysosomal and proteasomal pathways in atrophying muscle cells. Cell Metab 6: 472-483, 2007. 